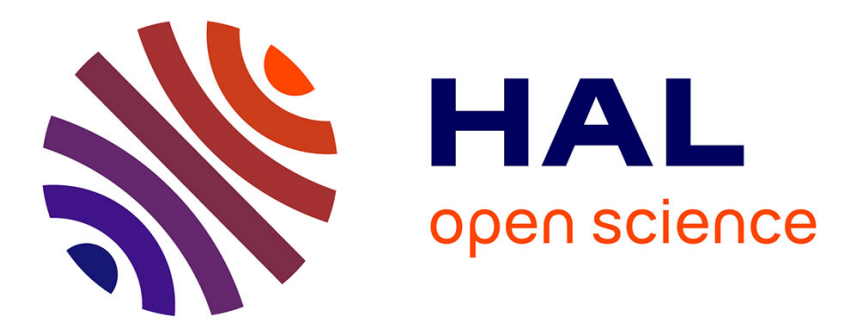

\title{
Research on the effect of liquid-liquid doping processes on the doped powders and microstructures of $\mathrm{W}-\mathrm{ZrO} 2(\mathrm{Y})$ alloys
}

Fangnao Xiao, Thierry Barriere, Gang Cheng, Qiang Miao, Shizhong Wei, Shiwei Zuo, Yanping Yang, Liujie Xu

\section{To cite this version:}

Fangnao Xiao, Thierry Barriere, Gang Cheng, Qiang Miao, Shizhong Wei, et al.. Research on the effect of liquid-liquid doping processes on the doped powders and microstructures of W-ZrO2(Y) alloys. Journal of Alloys and Compounds, 2021, 855, pp.157335. hal-03186578

\section{HAL Id: hal-03186578 https://hal.science/hal-03186578}

Submitted on 31 Mar 2021

HAL is a multi-disciplinary open access archive for the deposit and dissemination of scientific research documents, whether they are published or not. The documents may come from teaching and research institutions in France or abroad, or from public or private research centers.
L'archive ouverte pluridisciplinaire HAL, est destinée au dépôt et à la diffusion de documents scientifiques de niveau recherche, publiés ou non, émanant des établissements d'enseignement et de recherche français ou étrangers, des laboratoires publics ou privés. 


\section{Research on the effect of liquid-liquid doping processes on the doped powders and microstructures of $\mathrm{W}-\mathrm{ZrO} 2(\mathrm{Y})$ alloys}

Fangnao Xiao, Thierry Barriere, Gang Cheng, Qiang Miao, Shizhong Wei, Shiwei Zuo, Yanping Yang, Liujie Xu

\section{To cite this version:}

Fangnao Xiao, Thierry Barriere, Gang Cheng, Qiang Miao, Shizhong Wei, et al.. Research on the effect of liquid-liquid doping processes on the doped powders and microstructures of W-ZrO2(Y) alloys. Journal of Alloys and Compounds, Elsevier, 2021, 855, pp.157335 (12). hal-03186578

\section{HAL Id: hal-03186578 \\ https://hal.archives-ouvertes.fr/hal-03186578}

Submitted on 31 Mar 2021

HAL is a multi-disciplinary open access archive for the deposit and dissemination of scientific research documents, whether they are published or not. The documents may come from teaching and research institutions in France or abroad, or from public or private research centers.
L'archive ouverte pluridisciplinaire HAL, est destinée au dépôt et à la diffusion de documents scientifiques de niveau recherche, publiés ou non, émanant des établissements d'enseignement et de recherche français ou étrangers, des laboratoires publics ou privés. 
Graphical Abstract (for review)
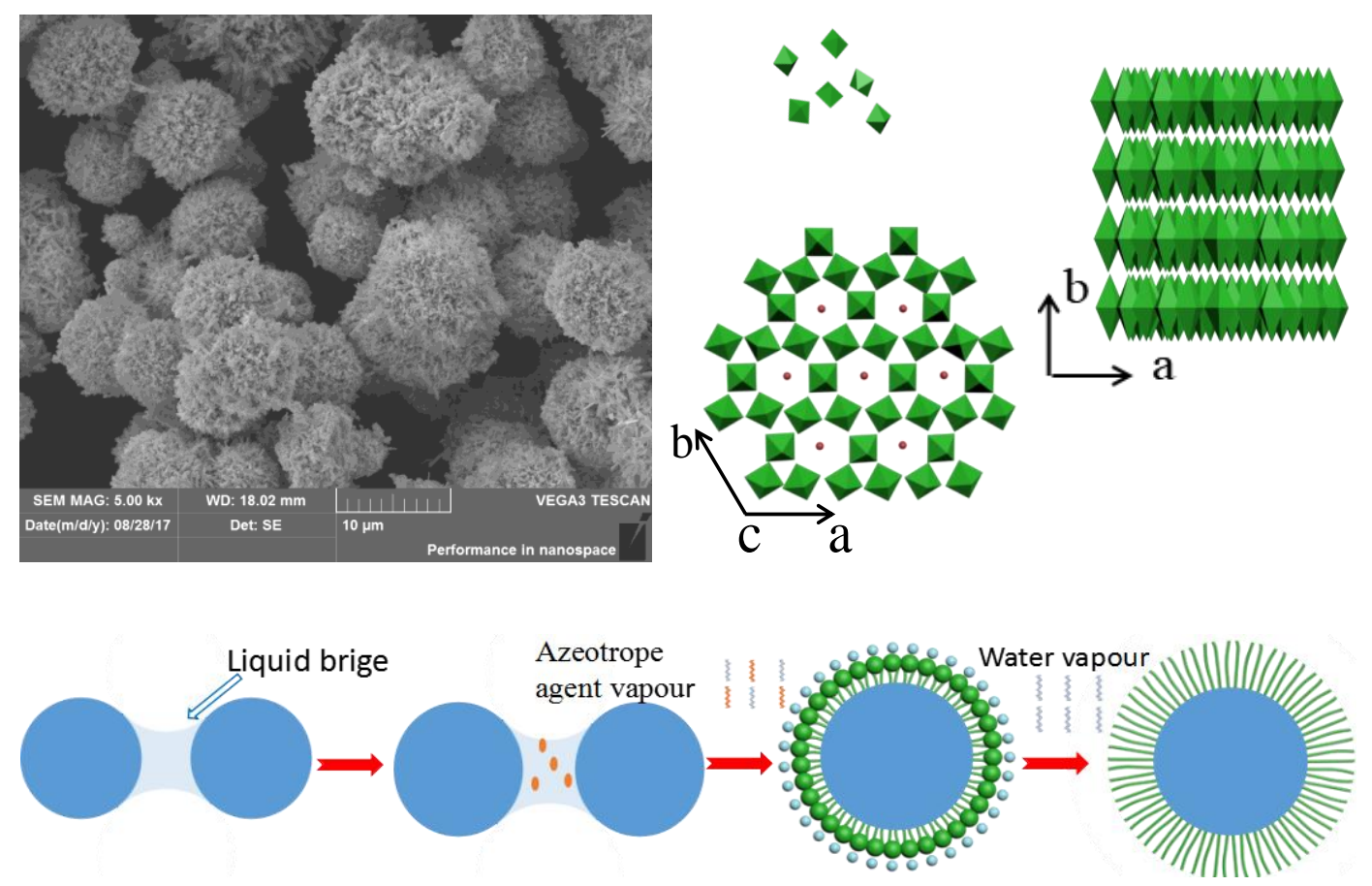


\section{Highlights}

1. Three novel liquid-liquid doping technique for preparing precursors were proposed.

2. Extremely homogeneous microspherical and flaky precursors were synthesized.

3. Synthesis mechanism of three precursors were investigated in detail, respectively.

4. Reaction mechanisms for synthesizing cubic $\mathrm{ZrO}_{2}$ in ternary liquid system were discussed.

5. Novel method offers a general pathway in industrial production of high quality ODS-W powders. 


\section{Credit Author Statement}

Shizhong Wei: Methodolgy; Qiang Miao and Shizhong Wei: Analysis; Fangnao Xiao, Yanping Yang, Shiwei Zuo: Experiments, Writing-Original draft preparation; Thierry Barriere and Gang Cheng: Methodolgy, Analysis, Writing-Reviewing; All authors: Discussions. 
${ }^{\star}$ Declaration of Interest Statement

\section{Declaration of interests}

The authors declare that they have no known competing financial interests or personal relationships that could have appeared to influence the work reported in this paper. 

doped powders and microstructures of $\mathrm{W}-\mathrm{ZrO}_{2}(\mathrm{Y})$ alloys Fangnao Xiao ${ }^{a, b, c}$, Thierry Barriere ${ }^{a}$, Gang Cheng ${ }^{b}$, Qiang Miao ${ }^{\mathrm{c} *}$, Shizhong Wei ${ }^{\mathrm{d} *}$, Shiwei Zuo ${ }^{c}$, Yanping Yang ${ }^{\mathrm{d}}$, Liujie $\mathrm{Xu}{ }^{\mathrm{d}^{*}}$

a Univ. Bourgogne Franche-Comté, FEMTO-ST Institute, CNRS/UFC/ENSMM/UTBM, Department of Applied Mechanics, 25000 Besançon, France

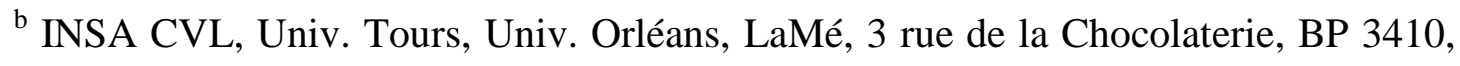
41034 Blois Cedex, France

${ }^{c}$ College of Material Science and Technology, Nanjing University of Aeronautics and Astronautics, 29 Yudao Street, Nanjing 210000, China

${ }^{\mathrm{d}}$ National Joint Engineering Research Center for abrasion control and molding of metal materials, Henan University of Science and Technology, Luoyang 471003, China

*Corresponding author

Fangnao Xiao

E-mail: fangnao.xiao@ univ-fcomte.fr

Full postal address:

FEMTO-ST Institute, Departement of Applied Mechanics, 24 chemin de

l'épitaphe, 25000, Besançon, France

Tel.: +33381666000 


\begin{abstract}
In previous researches, there are few studies on the mechanisms involved in liquid-liquid doping techniques for preparing oxide particle doped tungsten powders. In this research, based on different polytungstate species, three liquid-liquid doping techniques for synthesizing different doped precursor powders were proposed and compared. The extremely homogeneous hexagonal $\left(\mathrm{NH}_{4}\right)_{0.33} \mathrm{WO}_{3} \cdot \mathrm{H}_{2} \mathrm{O}$ microspheres and flaky $\left(\mathrm{NH}_{4}\right)_{6} \mathrm{H}_{2} \mathrm{~W}_{12} \mathrm{O}_{40} \cdot 5 \mathrm{H}_{2} \mathrm{O}$ were synthesized. The synthesis mechanisms of precursors, the doping processes and reaction mechanisms for preparing yttrium-stabilised $\mathrm{ZrO}_{2}$ in ternary liquid phase system were discussed. The doped powder prepared through azeotropic distillation method exhibits higher quality due to the highly dispersed $\mathrm{ZrO}_{2}(\mathrm{Y})$ phase uniformly distributed in flaky precursor, and the corresponding alloy possesses more excellent microstructure and mechanical properties. The proposed azeotropic distillation method offers a general pathway and is readily adapted to large-scale industrial production of high-quality oxide particle doped W powders.
\end{abstract}

Keywords: Hydrothermal process; Azeotropic distillation; ODS-W; Zirconia; Phase evolution.

\title{
1. Introduction
}

In recent decades, tungsten, an indispensable material, has been widely used in national defence, aerospace, metal processing, mining and oil drilling industries $[1,2]$. However, tungsten has a relatively high ductile-brittle transition temperature (DBTT) and a low recrystallization temperature [3]. Thermally stable oxide particles, such as 
$\mathrm{La}_{2} \mathrm{O}_{3}, \mathrm{Y}_{2} \mathrm{O}_{3}, \mathrm{HfO}_{2}, \mathrm{ZrO}_{2}$ and $\mathrm{CeO}_{2}$ dispersed in the tungsten matrix, can effectively inhibit recovery/recrystallization at high temperatures and decrease the DBTT, thereby improving the mechanical properties of tungsten alloy [4-9]. Therefore, the researches on the oxide dispersion-strengthened tungsten (ODS-W) have attracted considerable attention $[10,11]$.

The mechanical properties of tungsten materials are determined by the quality of tungsten powder to some extent [12-16]. Fu et al. [17] and Gamble et al. [18] found that the morphology and dimension of particles significantly influence powder flowability, dimension accuracy, surface roughness and mechanical properties of the manufactured tungsten parts. Impurities in tungsten powders (e.g. $\mathrm{O}$ and $\mathrm{N}$ ) segregate at grain boundaries (GBs), decreasing their cohesion and forming low-ductility tungsten alloys [19]. The agglomerates of tungsten powder particles affect the density and porosity of the tungsten products [12]. Therefore, the requirements for synthesis of high-quality powders (e.g. surface morphology, particle size and size distribution) have increased [20].

In the past several years, liquid-liquid ( $\mathrm{L}-\mathrm{L})$ methods involving molecular-level doping are used to prepare tungsten powder [27-34]. However, the doped tungsten powders in previous researches exhibit high degree of agglomeration, such as $\mathrm{W}-\mathrm{Y}_{2} \mathrm{O}_{3}$ powders [27, 32], W-Re powders [28], $\mathrm{W}-\mathrm{Sc}_{2} \mathrm{O}_{3}$ powders [29] and $\mathrm{W}-\mathrm{As}$ powders [34]. A higher degree of agglomeration may lead to the tough calcination and reduction process [28], inadequate reduction, non-uniform distribution of doping phase [30], high energy consumption and strictly controlled sintering process (i.e. the 
higher pressing loading, sintering temperature and advanced equipment) [31-33]. Moreover, the usual problem of agglomeration in powder is not conducive to the development process of net-shape accuracy powder metallurgy manufacturing, which requires higher flowability, purity and uniform distribution of doping phase.

In above studies, selected ammonium metatungstate (AMT) was selected as raw material. However, AMT, a polytungstic acid, exhibits high sensitivity to acidity [35], resulting in a complicated reaction mechanism during synthesis of precursor powders. Moreover, highly soluble AMT is prone to moisture absorption and caking and forms hard agglomerates during water evaporation [36]. However, in previous researches, the precursor powders' synthesis, solution acidity, reaction mechanism and refinement mechanism of precursor agglomeration have not been investigated in detail, resulting in the tedious works and poor repeatability. As reported in literatures $[37,38]$, the physical characteristics of the precursor powder, the phase evolution process and the evolution mechanisms greatly affect the resultant reduced powders. However, limited studies have focused on the synthesis of doped tungsten powder. Especially, in the preparation of W-ODS alloy involving liquid-liquid doping processes, there are few researches referring to the influence of precursor powders on the properties of powders and alloys. Dong et al, [22] used a wet chemical process to synthesize nanosized composite powder and then sintered $\mathrm{W}-\mathrm{Y}_{2} \mathrm{O}_{3}$ alloy by spark plasma sintering process. Nevertheless, there was no description about the influence of precursor powders. Y. Z. Hu et al. [27] studied the effect of yttrium doping on the formation and stability of $\beta$-tungsten powder based on the spray drying process. They 
focused on the phase and morphology evolution during all stages of the thermal treatment process. However, as usual, the solid spherical structures in precursor remained in the reduced powders. In the research of $\mathrm{Xu}$ et al. [31], the hydrothermal-hydrogen reduction process was employed to prepare the $\mathrm{La}_{2} \mathrm{O}_{3}$ doped ultra-fine tungsten powders. It indicated that the hydrothermal process was the most appropriate method to obtain a high-quality powder. However, the adopted raw materials of $\mathrm{Na}_{2} \mathrm{WO}_{4} \cdot 2 \mathrm{H}_{2} \mathrm{O}$ and $\mathrm{HCl}$ may lead to the introduction of $\mathrm{Na}^{+}$and $\mathrm{Cl}^{-}$ impurities.

In this research, given that that different polytungstate species exist in aqueous solutions with different acidities [35, 39], we propose three $\mathrm{L}-\mathrm{L}$ doping methods such as hydrothermal method (denoted as HM), sol-gel method (denoted as SM) and azeotropic distillation method (denoted as ZM) for synthesis of doped hexagonal $\left(\mathrm{NH}_{4}\right)_{0.33} \mathrm{WO}_{3} \cdot \mathrm{H}_{2} \mathrm{O}$, doped APT and doped AMT powders, respectively. The synthesis mechanisms, phase evolution and evolution mechanisms of the three precursor powders containing $\mathrm{W}$ and $\mathrm{Zr}$ phases were investigated in detail. Through the comparison of physical properties of the reduced doped tungsten powders and sintered alloys, $\mathrm{ZM}$ can prepared yttrium-stabilised zirconia $\left[\mathrm{ZrO}_{2}(\mathrm{Y})\right]$ doped tungsten powders $\left[\mathrm{W}-\mathrm{ZrO}_{2}(\mathrm{Y})\right]$ with higher quality than the products of the two other methods. Finally, the relationships between doping mechanisms with the microstructures and mechanical properties of sintered alloys were discussed in detail.

\section{Experimental procedure}

\subsection{Preparation of samples}


The soluble raw materials used for the synthesis of the doped tungsten powders were ammonium metatungstate $\left(\left(\mathrm{NH}_{4}\right)_{6} \mathrm{H}_{2} \mathrm{~W}_{12} \mathrm{O}_{40} \cdot 5 \mathrm{H}_{2} \mathrm{O}\right.$; grade $\mathrm{AR}$; AMT), zirconium nitrate $\left[\mathrm{Zr}\left(\mathrm{NO}_{3}\right)_{4} \cdot 5 \mathrm{H}_{2} \mathrm{O} ;\right.$ grade $\left.\mathrm{AR}\right] /$ zirconium oxychloride octahydrate $\left(\mathrm{ZrOCl}_{2} \cdot 8 \mathrm{H}_{2} \mathrm{O}\right.$ grade AR) and yttrium nitrate $\left(\left(\mathrm{Y}\left(\mathrm{NO}_{3}\right)_{3} \cdot 6 \mathrm{H}_{2} \mathrm{O}\right.\right.$; grade $\left.\mathrm{AR}\right)$. The chemical compositions of the samples were listed in Table 1.

Table 1 The chemical composition of the samples. (wt. \%)

\begin{tabular}{cccc}
\hline Samples & $\mathrm{W}$ & $\mathrm{ZrO}_{2}$ & $\mathrm{Y}_{2} \mathrm{O}_{3}$ \\
\hline $\mathrm{Z}_{1.0}$ & 98.873 & 1.0 & 0.127 \\
$\mathrm{Z}_{5.0}$ & 94.370 & 5.0 & 0.630 \\
\hline
\end{tabular}

In this research, three L-L doping techniques, which are HM, SM and ZM, respectively were adopted. Fig. 1 shows the preparation process of doped tungsten powders and tungsten alloys.

In $\mathrm{HM}$, $\left(\mathrm{NH}_{4}\right)_{6} \mathrm{H}_{2} \mathrm{~W}_{12} \mathrm{O}_{40} \cdot 5 \mathrm{H}_{2} \mathrm{O}$ was dissolved in distilled water and then the $\mathrm{pH}$ of the original solution was adjusted below 1.0 by adding nitric acid solution under stirring. The clear solution was transferred into Teflon-lined stainless steel autoclave. Specific amounts of $\mathrm{Zr}\left(\mathrm{NO}_{3}\right)_{4} \cdot 5 \mathrm{H}_{2} \mathrm{O}$ and $\mathrm{Y}\left(\mathrm{NO}_{3}\right)_{3} \cdot 6 \mathrm{H}_{2} \mathrm{O}$ were mixed with a contain amount of urea and then placed into another autoclave. The autoclaves were sealed and heated until the desired temperature of $170{ }^{\circ} \mathrm{C}$. After the reaction, the autoclaves were naturally cooled to room temperature. Distilled water was added to the mixture of the two reaction products under continuous stirring using an electric mixer for $2 \mathrm{~h}$. The mixture was filtered to obtain precursor powders. The preparation process of HM, was described elsewhere [40]. 
For powder prepared through $\mathrm{ZM}$ and $\mathrm{SM}$, commercial $\mathrm{ZrOCl}_{2} \cdot 8 \mathrm{H}_{2} \mathrm{O}$, $\mathrm{Y}\left(\mathrm{NO}_{3}\right)_{3} \cdot 6 \mathrm{H}_{2} \mathrm{O}$ and $\left(\mathrm{NH}_{4}\right)_{6} \mathrm{H}_{2} \mathrm{~W}_{12} \mathrm{O}_{40} \cdot \mathrm{xH}_{2} \mathrm{O}$ were separately dissolved in distilled water. The $\mathrm{Y}\left(\mathrm{NO}_{3}\right)_{3}$ solution was added slowly to the $\mathrm{ZrOCl}_{2} \cdot 8 \mathrm{H}_{2} \mathrm{O}$ solution under stirring. The mixture was homogenised under stirring for $20 \mathrm{~min}$ and gradually added to the $\left(\mathrm{NH}_{4}\right)_{6} \mathrm{H}_{2} \mathrm{~W}_{12} \mathrm{O}_{40} \cdot \mathrm{xH}_{2} \mathrm{O}$ solution while stirring for $3 \mathrm{~h}$ at room temperature to prepare the initial solution. In $\mathrm{ZM}$, the initial solution was heated to $93{ }^{\circ} \mathrm{C}$ with continuous stirring until precipitates were formed on the solution surface. The mixture of alcohol and butanol was used as azeotropic agent and added to the initial solution. The solution was then heated continuously until the precursor powder was formed. In $\mathrm{SM}$, the $\mathrm{pH}$ of the initial solution was adjusted to 7.0 by adding ammonia solution under stirring to obtain sols. Polyethylene glycol (PEG-1540) was used as dispersant to prevent agglomeration. The SM precursor powder was synthesized through the same procedures with ZM. Schematic graph of azeotropic distillation and sol-gel apparatus was shown in Fig. 2 [39].

The three different precursor powders were dried overnight at $90^{\circ} \mathrm{C}$ and calcined at $600^{\circ} \mathrm{C}$ for $4 \mathrm{~h}$ in a muffle furnace. The same calcination temperature as in previous study was applied [40]. The calcined powders were reduced by hydrogen reduction process at $900{ }^{\circ} \mathrm{C}$ for $2 \mathrm{~h}$ to obtain the reduced doped powders. $\mathrm{H}_{2}$ atmosphere were conventionally applied as a reducing atmosphere to reduce the oxide tungsten as reported in [27-34].

The reduced doped powders were pressed into rubber mould at $350 \mathrm{MPa}$ for 30 min by using cold isostatic pressing to obtain cylindrical billets of $\Phi 20 \mathrm{~mm} \times 30 \mathrm{~mm}$. 
The samples were then placed into medium-frequency induction sintering furnace under a hydrogen atmosphere $\left(\mathrm{H}_{2}\right)$. The sintering was conducted at $2400{ }^{\circ} \mathrm{C}$ for $4 \mathrm{~h}$ to prepare $\mathrm{W}-\mathrm{ZrO}_{2}(\mathrm{Y})$ alloys. The sintering kinetics were proposed for the same doped tungsten material by Luoyang aikemai tungsten \& molybdenum Technology Co. LTD., in China [3].

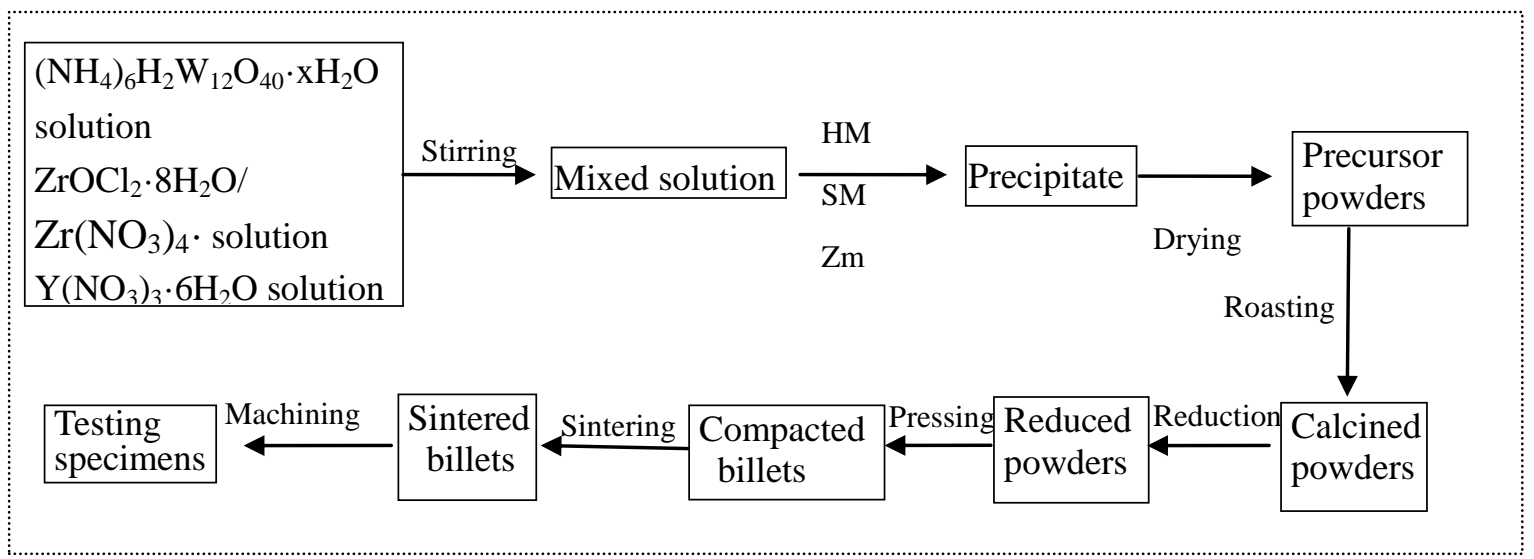

Fig. 1. Illustration of the process for the preparation of doped tungsten powders and tungsten alloys.

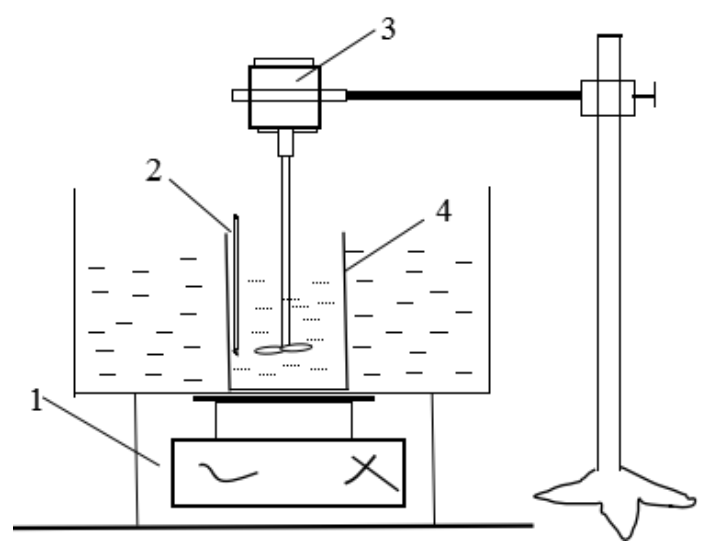

(1) - Electric-heated thermostatic water bath

(2) - Mercurial thermometer

(3) - Digital stirring

(4) - Beaker 
Fig. 2. Schematic diagram of azeotropic distillation and sol-gel apparatus.

\subsection{Measurement and analysis}

Particle size distribution was evaluated in the aqueous phase of the prepared powders by using the Mastersizer-2000 laser diffraction particle size analyser. The span value $(\psi)$ indicates the particle size distribution of the powder and was calculated using Eq. (1) [12].

$$
\Psi=\left(D_{90}-D_{10}\right) / 2 D_{50}
$$

where $\psi$ is the span value, and $D_{10}, D_{50}$ and $D_{90}$ are the corresponding particle sizes when the cumulative particle size distribution percentages reach $10 \%, 50 \%$ and $90 \%$, respectively.

The oxygen content in these powders was determined by a nitrogen/oxygen/hydrogen determination instrument (TCH-600, LECO). Specific surface area (SSA) was measured with a BET surface area analysis instrument (Autosorb-1, Quantachrome, USA). The average particle sizes of the doped tungsten powders were calculated based on the BET specific surface area by using the following equation [41]:

$$
d_{B E T}=6 /\left(S_{B E T} \cdot \rho_{\text {Theory }}\right)
$$

where $d_{B E T}$ is the average particle size, $S_{B E T}$ is the specific surface area of the powder and $\rho_{\text {Theory }}$ is the theoretical density of tungsten (i.e. $19.3 \mathrm{~g} / \mathrm{cm}^{3}$ ).

Absolute densities of tungsten alloys were calculated using the Archimedes' principle, and relative densities were determined using the apparent volume mass divided by the theoretical value of $18.82 \mathrm{~g} / \mathrm{cm}^{3}$ [42]. Vickers hardness tests were 
conducted under a load of $200 \mathrm{~g}$ with a dwelling time of $20 \mathrm{~s}$. Ten different fields were randomly selected, and the mean value was obtained. Cylindrical specimens with size of $\Phi 6 \mathrm{~mm} \times 10 \mathrm{~mm}$ were prepared by machining the sintered alloys for compression tests. The ends of the samples were ground and polished flat by $\mathrm{Al}_{2} \mathrm{O}_{3}$ paper of approximately 1500 meshes. Compression tests were carried out at room temperature using a universal material machine (AG-I250KN) with $1.0 \mathrm{~mm} / \mathrm{min}$ speed of compression. Hot compression tests were conducted on a Gleeble-1500D testing machine at $1000{ }^{\circ} \mathrm{C}$ with a strain rate of $1.0 \mathrm{~s}^{-1}$.

The morphology, microstructure and phase composition of powders and alloys were studied by scanning electron microscope (SEM, VEGA-SBH), back scatter electron image (BSE, VEGA-SBH) and energy-dispersive spectrometer (EDS), respectively. X-ray diffraction (XRD, Brux D8 type) was carried out to characterize the phase's compositions. Transmission electron microscopy (TEM) and electron diffraction pattern (SAEDP) were employed to observe the microstructure and crystal structure of the doping phase.

\section{Results and analysis}

\subsection{Analysis of precursor powders synthesized through the three $L-L$ methods}

As shown in Fig. 3a, the precursor powder prepared through HM exhibits a spherical structure and an average particle size of $3 \mu \mathrm{m}$. Based on the XRD pattern of the powder as shown in Fig 3b, all of the diffraction peaks agree well with the standard data file (PDF\#15-0217, $a=b=0.7388 \mathrm{~nm}, c=0.7551 \mathrm{~nm}$ ). Thus, these powders can be indexed to hexagonal $\left(\mathrm{NH}_{4}\right)_{0.33} \mathrm{WO}_{3} \cdot \mathrm{H}_{2} \mathrm{O}$. 
Fig. 3c shows that the synthesized powders through SM are mainly composed of large particles with size of 30-60 $\mu \mathrm{m}$. Most particles have an angular shape and some of them are incomplete. The magnified image in Fig. $3 \mathrm{~d}$ reveals numerous small particles around or attached to large particles. The EDX analysis reveals that fine particles contain $\mathrm{Zr}$-rich phase. The corresponding positions and intensity values of the diffraction peaks illustrated in Fig. $3 \mathrm{~b}$ are in good agreement with the XRD pattern of the standard $\left(\mathrm{NH}_{4}\right)_{10} \mathrm{H}_{2} \mathrm{~W}_{12} \mathrm{O}_{42} \cdot 4 \mathrm{H}_{2} \mathrm{O}\left(\mathrm{APT} \cdot 4 \mathrm{H}_{2} \mathrm{O}\right)(\mathrm{PDF} \# 49-1642)$ [43-45]. The APT $4 \mathrm{H}_{2} \mathrm{O}$ powders are usually synthesized through wet chemical method, so the complicated peaks exist in XRD patterns $[43,45]$. This finding indicates that the synthesized powder consists of APT $4 \mathrm{H}_{2} \mathrm{O}$, which can be confirmed by their square structure. The synthesized APT $4 \mathrm{H}_{2} \mathrm{O}$ powders possess the same structure [45]. In other words, APT $4 \mathrm{H}_{2} \mathrm{O}$ can be prepared by adding $\mathrm{NH}_{3} \cdot \mathrm{H}_{2} \mathrm{O}$ to the AMT solution because of the reversible reaction (Eq. 3) between AMT and APT. This is in good agreement with the presence of $\left(\mathrm{HW}_{6} \mathrm{O}_{21}\right)^{5-}$ ions as listed in Table 2 [39]. The main characteristic parameters of the three precursor powders obtained with different powder processing technology are summarized in Table 3.

$$
\left(\mathrm{NH}_{4}\right)_{6}\left(\mathrm{H}_{2} \mathrm{~W}_{12} \mathrm{O}_{40}\right) \cdot x \mathrm{H}_{2} \mathrm{O}+4 \mathrm{NH}_{3} \cdot \mathrm{H}_{2} \mathrm{O}=\left(\mathrm{NH}_{4}\right)_{10}\left(\mathrm{H}_{2} \mathrm{~W}_{12} \mathrm{O}_{42}\right) \cdot \mathrm{yH}_{2} \mathrm{O}
$$

Table 2 Polytungstate species in solutions containing different $\mathrm{pH}$ values [39].

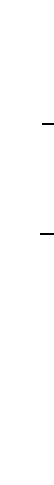

$\mathrm{pH}$

Reversible reaction equation

Reaction products Common name value

$\mathrm{pH} \leq 1 \quad\left(\mathrm{H}_{2} \mathrm{~W}_{12} \mathrm{O}_{40}\right)^{6-}+6 \mathrm{H}^{+}+32 \mathrm{H}_{2} \mathrm{O}=12\left(\mathrm{H}_{2} \mathrm{WO}_{4} \cdot 2 \mathrm{H}_{2} \mathrm{O}\right) \quad \mathrm{H}_{2} \mathrm{WO}_{4} \cdot 2 \mathrm{H}_{2} \mathrm{O} \quad$ Tungstic acid 
$\mathrm{pH}=2 \quad \mathrm{H}_{2} \mathrm{~W}_{12} \mathrm{O}_{40}{ }^{6-}+\mathrm{H}^{+}=\mathrm{HW}_{12} \mathrm{O}_{39}{ }^{5-}+\mathrm{H}_{2} \mathrm{O}$

$$
\mathrm{H}_{2} \mathrm{~W}_{12} \mathrm{O}_{40}{ }^{6-}
$$

$\mathrm{pH}=4 \quad \mathrm{HW}_{12} \mathrm{O}_{39}{ }^{5-}+2 \mathrm{H}_{2} \mathrm{O}+\mathrm{OH}^{-}=2\left(\mathrm{H}_{3} \mathrm{~W}_{6} \mathrm{O}_{21}\right)^{3-}$

$\mathrm{pH}>6 \quad\left(\mathrm{H}_{3} \mathrm{~W}_{6} \mathrm{O}_{21}\right)^{3-}+2 \mathrm{OH}^{-}=\left(\mathrm{HW}_{6} \mathrm{O}_{21}\right)^{5-}+2 \mathrm{H}_{2} \mathrm{O}$

$$
\left(\mathrm{HW}_{6} \mathrm{O}_{21}\right)^{5-}+3 \mathrm{H}_{2} \mathrm{O}+7 \mathrm{OH}^{-}=6\left(\mathrm{HWO}_{4}\right)^{-}+\mathrm{H}^{+}+7 \mathrm{OH}^{-}=6 \mathrm{WO}_{4}{ }^{2-}+
$$

$\mathrm{pH}>9$ $7 \mathrm{H}^{+}+7 \mathrm{OH}^{-}$$$
/ \mathrm{HW}_{12} \mathrm{O}_{39}{ }^{5-}
$$

$\left(\mathrm{H}_{3} \mathrm{~W}_{6} \mathrm{O}_{21}\right)^{3-}$

Pseudo-AMT

$\left(\mathrm{HW}_{6} \mathrm{O}_{21}\right)^{5-}$

Paratungstate

Metatungstate

$$
\mathrm{WO}_{4}{ }^{2-} \quad \text { Tungstate ion }
$$

For the precursor powder prepared through ZM, when only alcohol was used as azeotrope dispersant, the powder particles possess a gravel-like structure and a mean particle size of $50 \mu \mathrm{m}$ (Fig. 3e). The profile of individual particle is clearly visible. When the mixture of alcohol and n-butyl alcohol was used as azeotrope dispersant, the gravel-like structure changed into the flake structure (Fig. 3f). The morphological transition of precursor powders can be attributed to the physical properties of the raw material (AMT) and the effect of azeotrope dispersant on particle dispersion. Fig. 3b shows the corresponding XRD patterns of the precursor powders through ZM. Seen from these peaks, most diffraction peaks match well with those of commercial AMT powder. However, some other complicated diffraction peaks are also observed in the pattern because AMT is partially decomposed to produce intermediates, such as $\mathrm{W}_{\mathrm{x}} \mathrm{O}_{\mathrm{y}}$, $\mathrm{NH}_{4} \mathrm{NO}_{3}$ and $\mathrm{Zr}\left(\mathrm{WO}_{4}\right)_{2}$, during water evaporation (Eq. 4) [46]. These insoluble substances, providing numerous primary nucleation sites, remain suspended in the solution under high stirring. As water evaporates, the newly generated AMT 
crystallite is induced to nucleate heterogeneously to grow into flake structure (inset of

Fig. 3e). The flake precursor powders with high surface areas were used to prepare the following powders and alloys.

$$
\begin{aligned}
& \left(\mathrm{NH}_{4}\right)_{6} \mathrm{H}_{2} \mathrm{~W}_{12} \mathrm{O}_{40} \cdot \mathrm{xH}_{2} \mathrm{O}+2 \mathrm{Zr}\left(\mathrm{NO}_{3}\right)_{4}=6 \mathrm{NH}_{3} \uparrow+8 \mathrm{HNO}_{3} \uparrow+\mathrm{WO}_{3} \cdot \mathrm{mH}_{2} \mathrm{O} \downarrow+ \\
& 2 \mathrm{Zr}\left(\mathrm{WO}_{4}\right)_{2} \cdot \mathrm{nH}_{2} \mathrm{O} \downarrow
\end{aligned}
$$
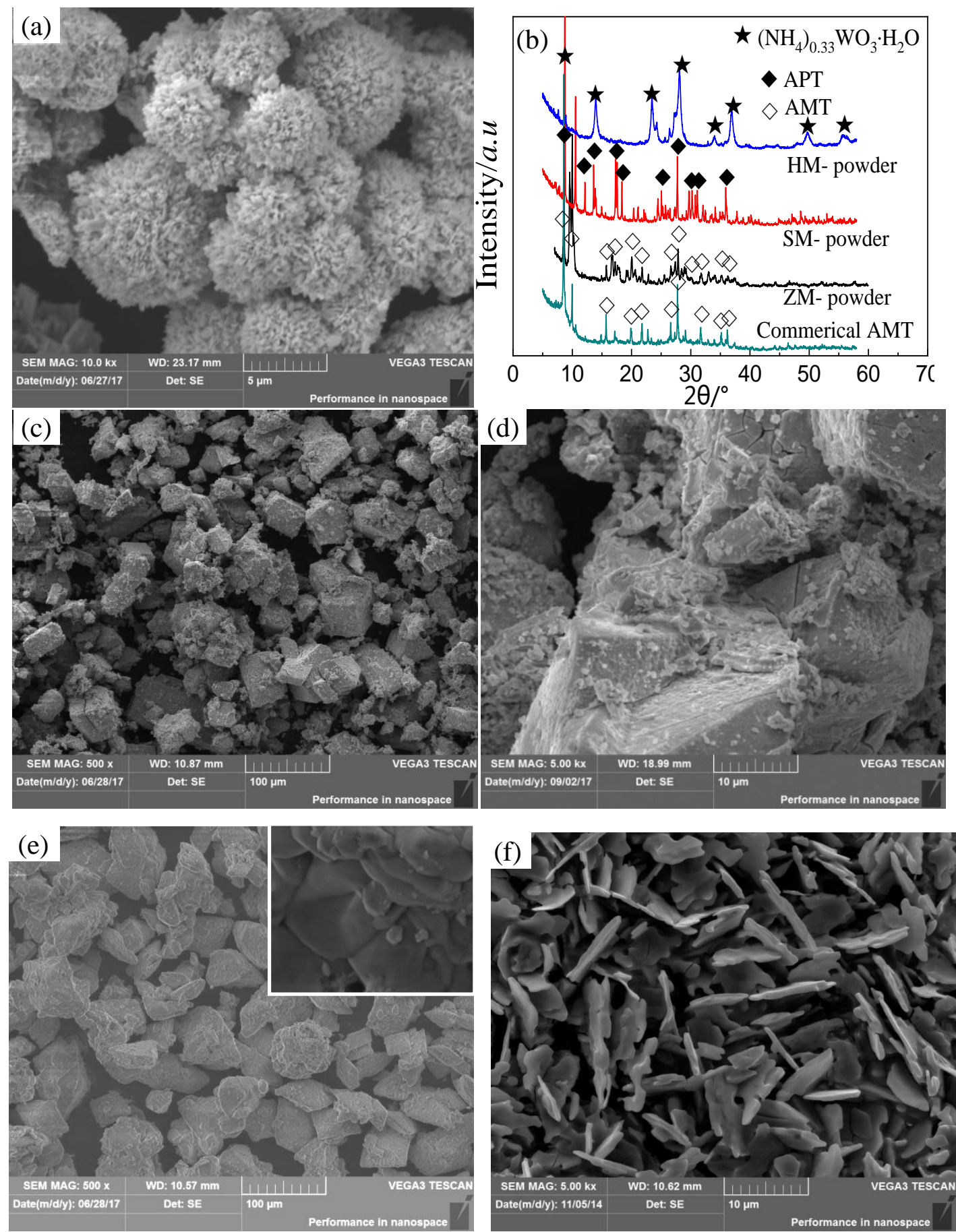
Fig. 3 Morphologies and phase compositions of precursors synthesized through different L-L doping processes: (a) HM; (b) XRD patterns of three precursor powders; (c, d) SM; (e) ZM with alcohol used as azeotrope dispersant; (f) ZM with alcohol and n-butyl alcohol used as azeotrope dispersants.

Table 3 Characteristic parameters of the three precursor powders

\subsection{Analysis of reduced doped powders}

Fig. 4 shows the SEM micrographs of the three doped tungsten powders with $1.0 \% \mathrm{ZrO}_{2}(\mathrm{Y})$ reduced at $900{ }^{\circ} \mathrm{C}$ for $2 \mathrm{~h}$. The tungsten powder particles prepared by three $\mathrm{L}-\mathrm{L}$ methods were coated by cloudy containing-( $\mathrm{Zr}, \mathrm{Y})$ oxide phase by the analysis of element composition. However, the three powders have obvious differences in morphology and particle size.

Fig. 4 a shows that the HM-powder consists of multifaceted particles with a mean size of $3.75 \mu \mathrm{m}$ (Table 4). The powder particles have a clear profile, indicating the lower degree of agglomerates compared to other two powders. This may be attributed to the dispersedly microspherical microstructure in HM- precursor powder. 
Moreover, the HM-powder has the lowest span value $\psi$ (Table 4), indicating the narrowest particle size distribution (Fig. 4d) [12].

As shown in Fig. 4b, the SM- powder exhibits larger mean particle size and span value with lower internal stress than the HM- and ZM-powders (Table 4). The SM-powder exhibits the widest particle size distribution. Fig. 4b shows that some spongy particles are embedded into the aggregates. The EDS analysis (Fig. 4e) of selected area A reveals that the spongy particles consist of $\mathrm{Zr}, \mathrm{Y}, \mathrm{O}$ and $\mathrm{W}$, which confirms the presence of zirconium and yttrium oxide phases. The formation of spongy particles may be explained as follows. The $\mathrm{pH}$ value increases to 7 by adding ammonia solution into the original solution, the formed $\mathrm{ZrY}(\mathrm{OH})_{\mathrm{x}}$ sols are full of $-\mathrm{OH}$ groups, which form extensive hydrogen bonds between neighbouring containing-(Zr, Y) particles. When these $-\mathrm{OH}$ groups are eliminated during drying or calcinations/reduction, containing-(Zr, Y) particle agglomerates are formed through strong intercrystallite bonding between neighbouring particles during the removal of the surface hydroxyl groups. The particles are consolidated in the calcination and reduction steps by the following reactions [Eqs. $(5,6)][47,48]$ :

$$
\begin{aligned}
& \mathrm{Zr}-\mathrm{OH}+\mathrm{HO}-\mathrm{Zr}=\mathrm{Zr}-\mathrm{O}-\mathrm{Z}+\mathrm{H}_{2} \mathrm{O} \\
& \mathrm{Y}-\mathrm{OH}+\mathrm{HO}-\mathrm{Y}=\mathrm{Y}-\mathrm{O}-\mathrm{Y}+\mathrm{H}_{2} \mathrm{O}
\end{aligned}
$$

The ZM-doped tungsten powder has smaller particle size than the two other powders (Fig. 4c), as also confirmed by the lowest mean particle size and $\mathrm{d}_{\text {bet }}$ size of $1.45 \mu \mathrm{m}$ and $1.15 \mu \mathrm{m}$, respectively. Although the ZM-powder obtains the medium span value, most particles have a size of $0.3 \mu \mathrm{m}$ to $3.5 \mu \mathrm{m}$. Hence, $\mathrm{ZM}$ can be used to 
prepare smaller doped tungsten powder particle than the two other methods. This is because that the loose and flaky morphology of the ZM-precursor powder helps the strong penetration of reducing hydrogen and the escape of the reduction products [such as $\mathrm{H}_{2} \mathrm{O}, \mathrm{WO}_{2}(\mathrm{OH})_{2}$ ]. As a result, fine and homogeneous $\mathrm{ZM}$-doped powder particles can be obtained through high-temperature reduction. The small size of doped tungsten powder particle is not only favourable for producing small tungsten grains but also for improving the distribution homogeneity of the doped phase [29, 49]. This finding is in agreement with the analysis of the alloy's microstructure in Fig. 5.
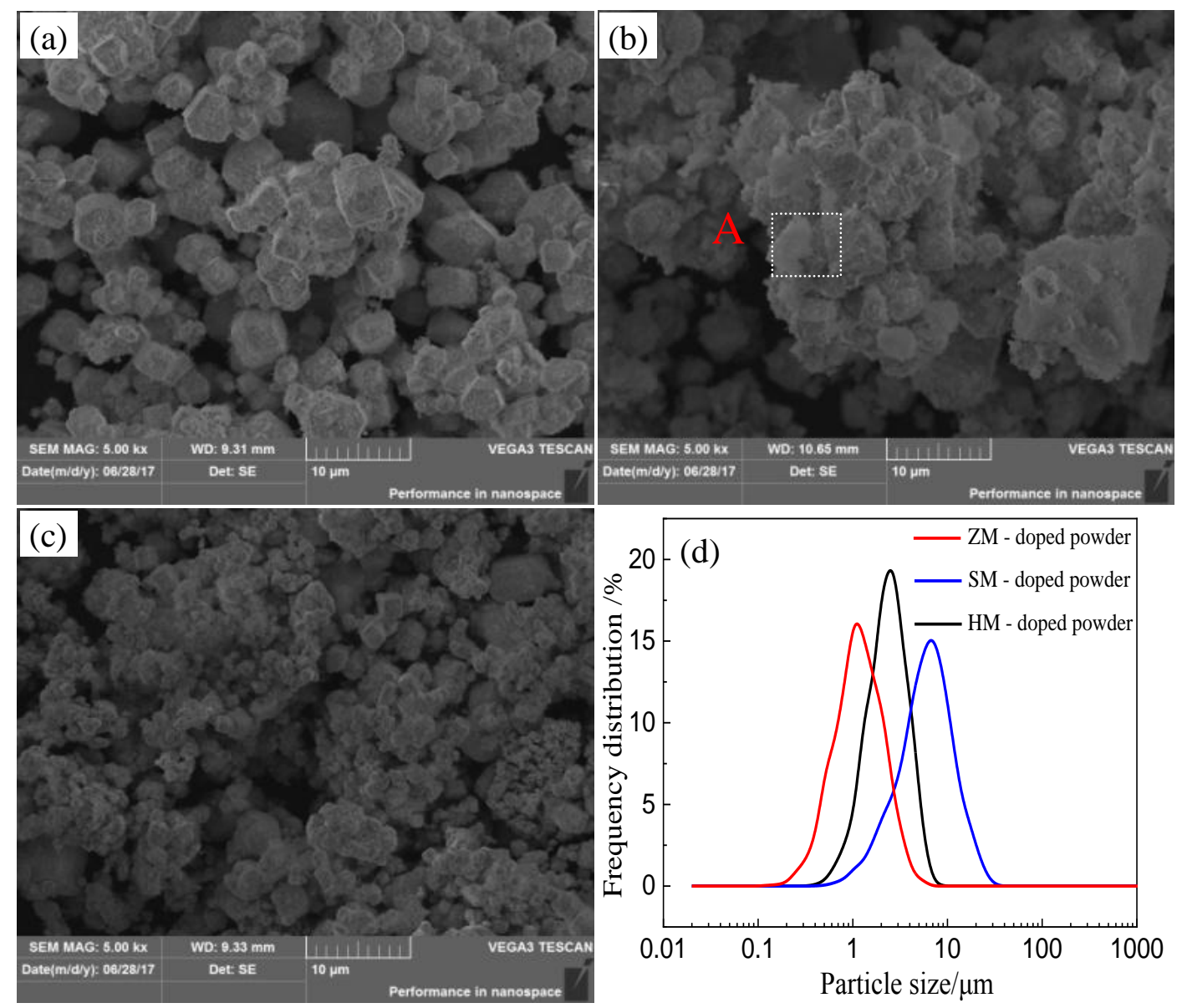


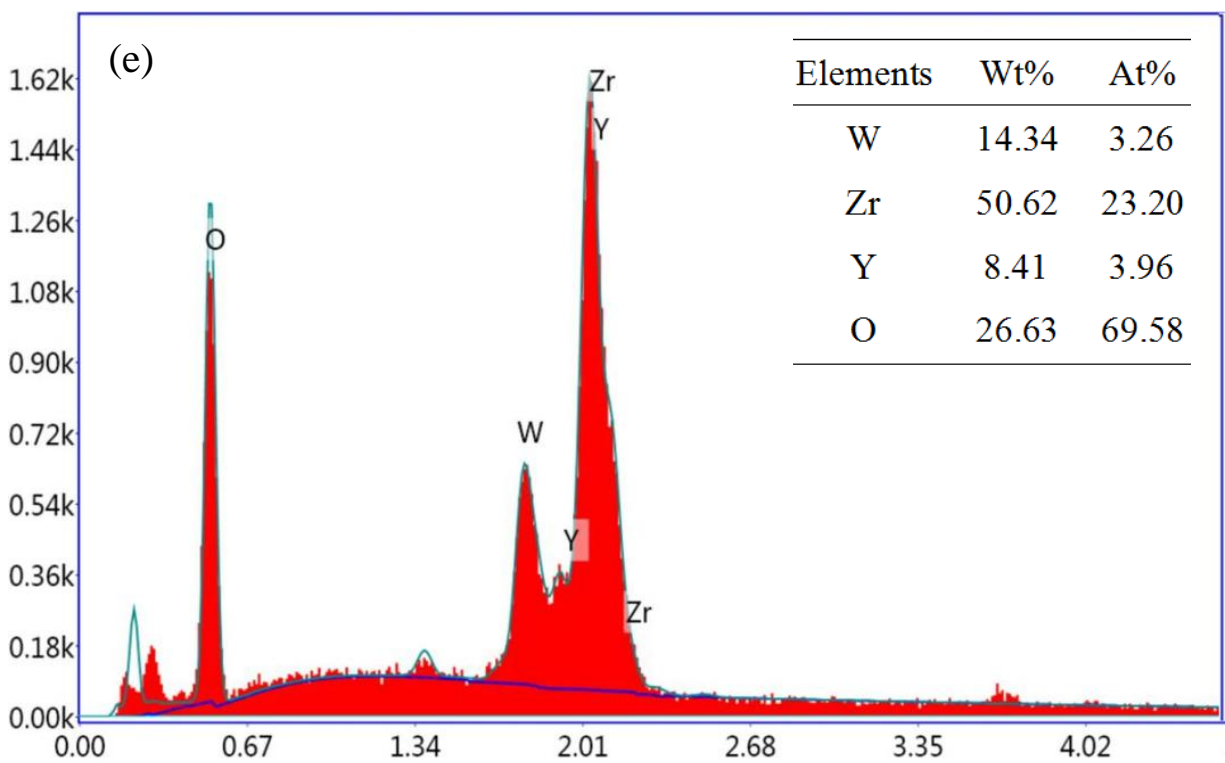

Fig. 4 SEM images of different doped powders reduced at $900{ }^{\circ} \mathrm{C}$ for $2 \mathrm{~h}$ : (a) HMdoped powder; (b) SM- doped powder; (c) ZM- doped powder and (d) particle size distribution of three doped powders; (e) EDS spectrum corresponding to the selected area A in Fig. 4 b.

Table 4 Characteristic parameters of the three kinds of powders.

\begin{tabular}{ccccccc}
\hline \multirow{2}{*}{ Powders } & Mean particle & Oxygen & SSA & $\mathrm{d}_{\mathrm{BET}}$ & Span & Internal \\
& size $(\mu \mathrm{m})$ & $(\mathrm{ppm})$ & $\left(\mathrm{m}^{2} / \mathrm{g}\right)$ & $(\mu \mathrm{m})$ & value $\psi$ & \\
& & & & & & $(\%)$ \\
\hline HM- powder & 3.75 & 425 & 0.168 & 1.85 & 0.70 & 0.06 \\
SM- powder & 6.21 & 378 & 0.231 & 1.35 & 0.92 & 0.04 \\
ZM- powder & 1.45 & 660 & 0.271 & 1.15 & 0.76 & 0.08 \\
\hline
\end{tabular}

\section{Microstructure and properties of alloys}

Fig. 5 shows the SEM and BSE images of the compressive fracture surfaces of alloys obtained from the three doped powders. Alloys prepared through HM, SM and 
ZM were denoted as HM-alloy, SM-alloy and ZM- alloy, respectively. The grains of HM-alloy have an average size of $3.6 \mu \mathrm{m}$ and possess the morphology of the HM-doped tungsten powder particle. The metallurgical point contacts were formed after sintering, leading to the lower density of the HM-alloy compared with the two other alloys (Table 5). This finding may be due to the low density of the green compact owing to the large powder particle size and the large diffusion distance of $\mathrm{W}$ atoms during sintering. Moreover, the BSE image (Fig. 5b) shows that most $\mathrm{ZrO}_{2}(\mathrm{Y})$ particles in HM-alloy have a spherical shape and an uniform size. The average size of $\mathrm{ZrO}_{2}(\mathrm{Y})$ particles is $1.5 \mu \mathrm{m}$, having the medium particle size compared with the $\mathrm{ZrO}_{2}(\mathrm{Y})$ particle size in two other alloys (Table 5).

As shown in Fig. 5 (c and e), the grain boundaries of SM- and ZM-alloys have formed metallurgical face-contacts and are more compacter than those of HM-alloy. As shown in Fig. 5c, numerous dense grain areas were observed because of the presence of numerous particle aggregates in the SM-doped powder. The large particles in the aggregates easily merge with the small particles, leading to the sharp growth of grains and formation of dense grain areas [50]. However, some deep holes can be observed on the fracture surface, causing a dramatic decrease in the density of SM-alloy. Fig. 5d shows that some adhesive $\mathrm{ZrO}_{2}(\mathrm{Y})$ particles (as marked by white circles) exist on fracture surface. The average size of $\mathrm{ZrO}_{2}(\mathrm{Y})$ particles in $\mathrm{SM}$-alloy is approximately $2.1 \mu \mathrm{m}$, which is the largest over the two other alloys. The SEM and BSE images of ZM-alloy show its excellent microstructure [Figs. 5(e, f)]. The microstructure shows that uniform distribution of fine $\mathrm{ZrO}_{2}(\mathrm{Y})$ particles with size of 
0.5-2.0 $\mu \mathrm{m}$ and a highly compact microstructure without obvious pores on the fracture surface. Table 5 shows that $\mathrm{ZM}$-alloy has the highest relative density, smallest tungsten grain and smallest $\mathrm{ZrO}_{2}(\mathrm{Y})$ particle size than the two other alloys. Given that these three alloys were pressed and sintered through the same process, the excellent microstructure could be due to the high quality of doped tungsten powder. Hence, ZM is more suitable for obtaining high-quality doped tungsten powder than HM and SM.
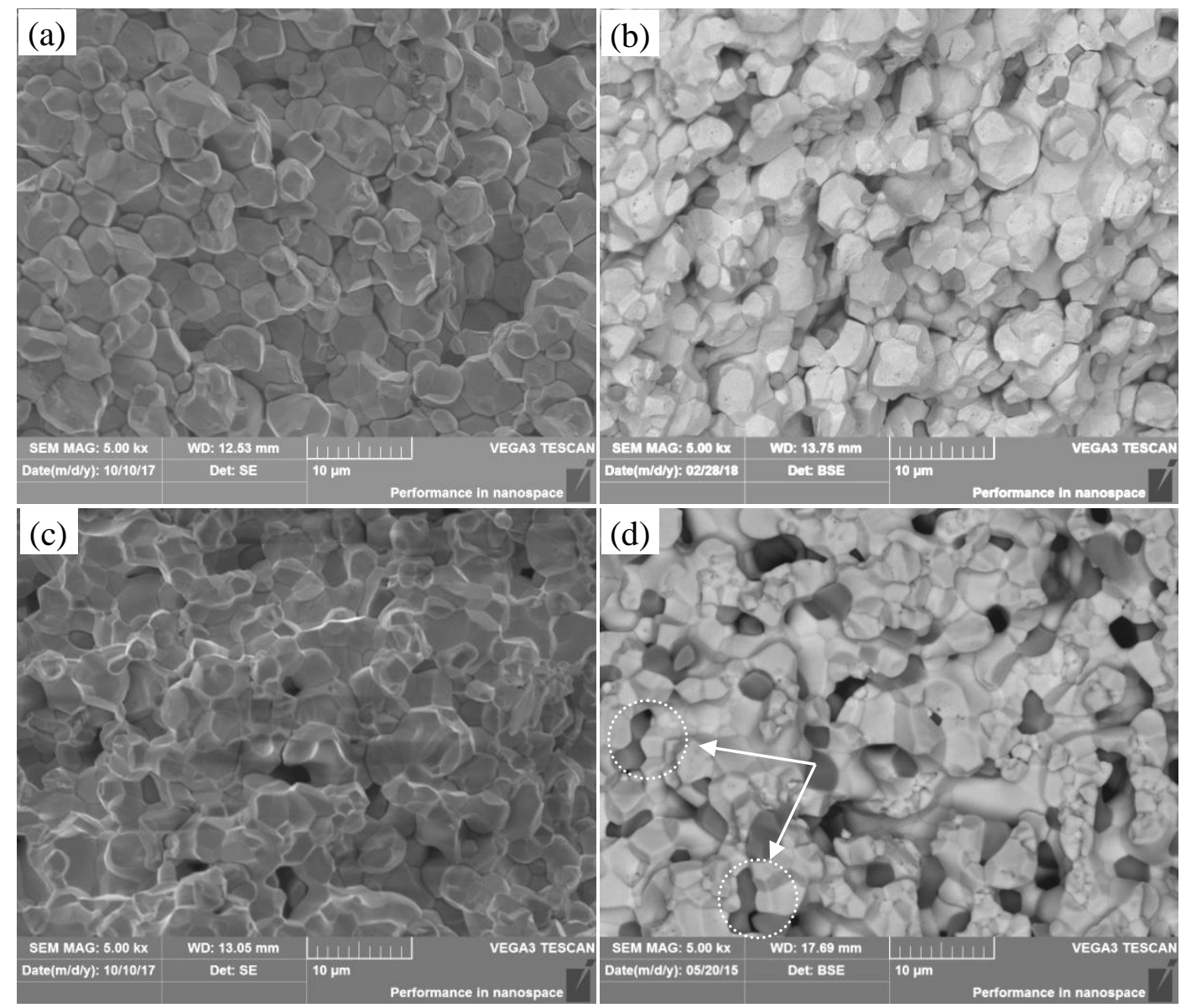


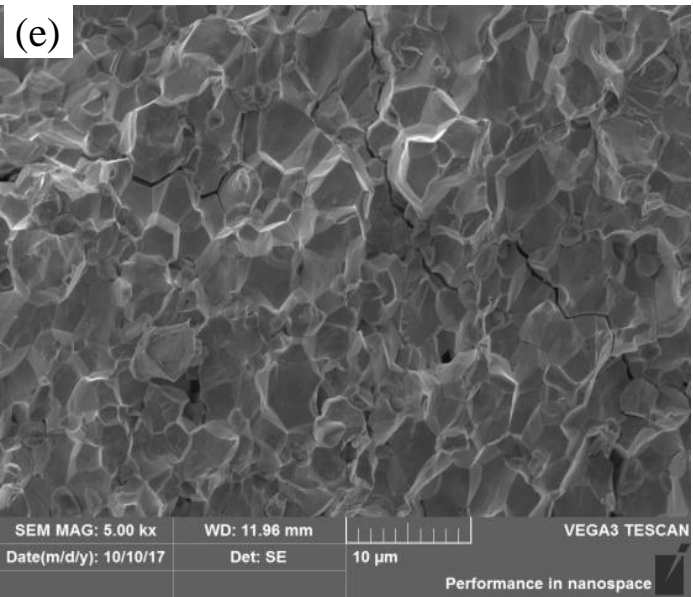

Fig. 5 SEM and BSE images of fracture surfaces of three alloys compressive-tested at room temperature: (a) SEM and (b) BSE images of the HMalloy; (c) SEM and (d) BSE images of the SM- alloy; (e) SEM and (f) BSE images of the ZM- alloy. 
Table 5 Microstructure and mechanical properties of three alloys.

\begin{tabular}{lccccc}
\hline & Grain /oxide & & Microhardness & \multicolumn{2}{c}{ Compressive strength (MPa) } \\
Alloys & particle size & Density $\left(\mathrm{g} / \mathrm{cm}^{3}\right)$ & & \multicolumn{2}{c}{$/$ /critical failure strain } \\
\cline { 4 - 5 } & $(\mu \mathrm{m})$ & $/(\% \mathrm{RD})^{\mathrm{a}^{*}}$ & & $25^{\circ} \mathrm{C}$ & $1000{ }^{\circ} \mathrm{C}$ \\
\hline $\mathrm{HM}$-alloy & $3.6 / 1.5$ & $15.88 / 84.37$ & 223 & $1050 / 0.18$ & $225 /-$ \\
$\mathrm{SM}$-alloy & $3.2 / 2.1$ & $15.53 / 82.5$ & 295 & $998 / 0.10$ & $265 /-$ \\
$\mathrm{ZM}$-alloy & $2.6 / 1.3$ & $16.48 / 87.6$ & 463 & $1410 / 0.13$ & $296 /-$ \\
\hline
\end{tabular}

$\mathrm{a}^{*}$ Relative density

TEM and SAEDP observations were carried out to investigate the crystal structure of $\mathrm{ZrO}_{2}(\mathrm{Y})$ in the three alloys (Fig. 6). As shown in Figs. 6 (a, c, d), the particle sizes of $\mathrm{ZrO}_{2}(\mathrm{Y})$ in the $\mathrm{HM}$ - and $\mathrm{ZM}$-alloys are in the range from $30 \mathrm{~nm}$ to $120 \mathrm{~nm}$, and the corresponding SAEDP results reveal the zirconia phase of $\mathrm{c}-\mathrm{ZrO}_{2}(\mathrm{Y})$ $(\mathrm{Fm}-3 \mathrm{~m})$ with face-centred cubic close structure along the zone axis of [-112] and [011]. The SAEDP result of SM-alloy confirms that the $\mathrm{ZrO}_{2}(\mathrm{Y})$ phase is the tetragonal crystal structure along the zone axis of [010]. Moreover, the TEM micrograph shows that large $\mathrm{ZrO}_{2}(\mathrm{Y})$ particles with size ranging from $200 \mathrm{~nm}$ to 600 $\mathrm{nm}$ tend to aggregate, which is consistent with the SEM observation in Fig. 5d. The above analysis indicates that the crystal structure of $\mathrm{ZrO}_{2}$ can also be stabilised among three alloys after high temperature sintering. 


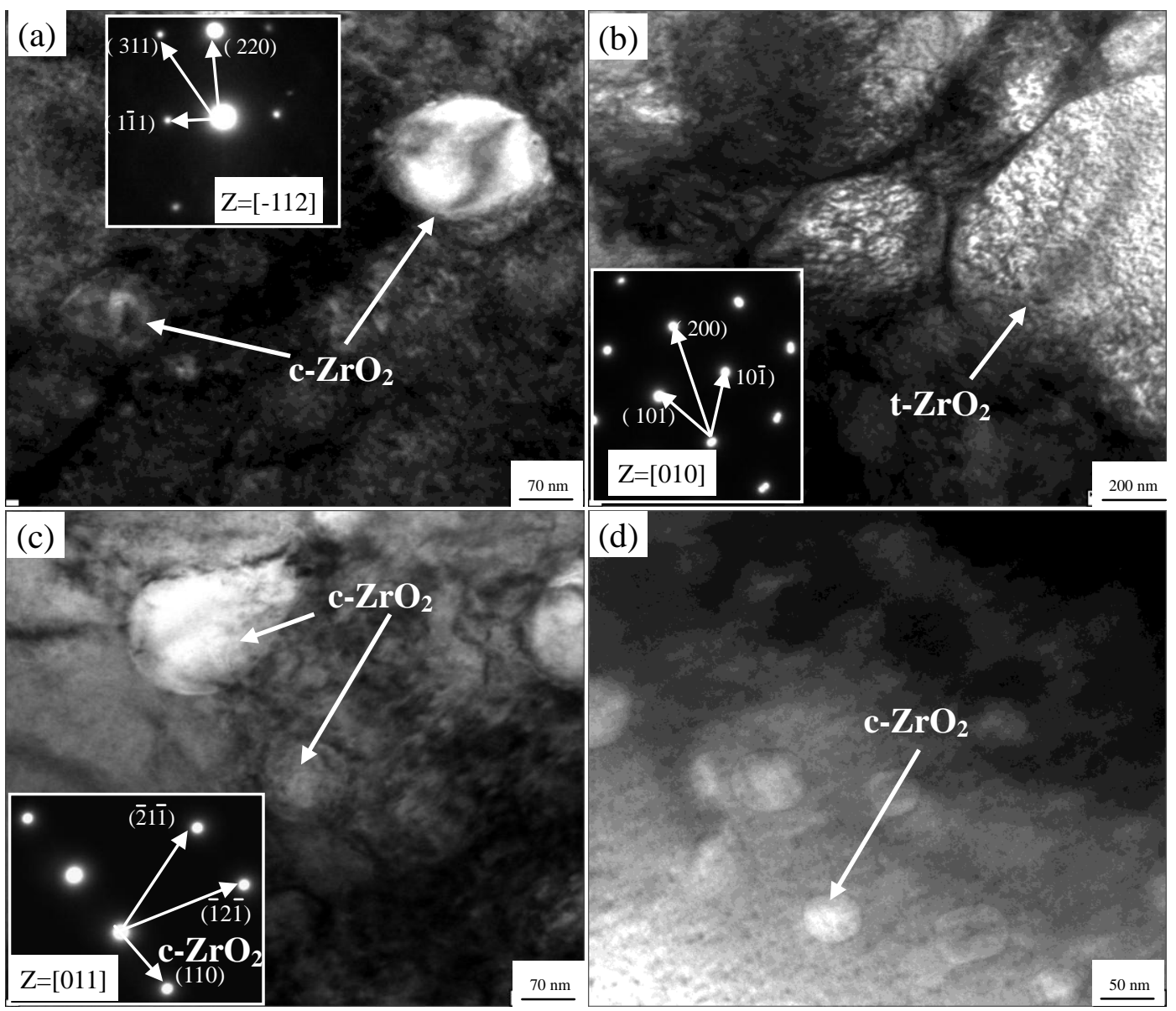

Fig. 6 TEM image and SAED pattern of the three $\mathrm{W}-\mathrm{ZrO}_{2}(\mathrm{Y})$ alloys: (a) the HMalloy; (b) the SM- alloy and (c, d) the ZM- alloy.

The crystal structure of $\mathrm{Zr}(\mathrm{Y}) \mathrm{O}_{2}$ particles in alloys would result from the $\mathrm{Zr}(\mathrm{Y}) \mathrm{O}_{2}$ particles in doped powders prepared through different $\mathrm{L}-\mathrm{L}$ doping processes. The XRD patterns of three doped tungsten powders with 5.0 wt. $\% \mathrm{ZrO}_{2}(\mathrm{Y})$ were obtained after reduction at $900^{\circ} \mathrm{C}$ for $2 \mathrm{~h}$ (Fig. 7). Detailed examination reveals a weak peak at $30^{\circ}$, followed by three diffraction peaks at $2 \theta=35^{\circ}, 50^{\circ}$ and $59^{\circ}$, respectively. Meanwhile, no obvious peaks were found on both sides of the peak at $30^{\circ}$. Therefore, it can be concluded that $\mathrm{Y}_{2} \mathrm{O}_{3}$-stabilised $\mathrm{ZrO}_{2}$ phases can be obtained in doped tungsten powders through the three $\mathrm{L}-\mathrm{L}$ doping methods combined with calcination-continuous reduction. 
Clustering $\mathrm{ZrO}_{2}$ and $\mathrm{Y}_{2} \mathrm{O}_{3}$ is the premise of forming stabilised $\mathrm{ZrO}_{2}$ phase [36]. The formation of stabilised $\mathrm{ZrO}_{2}$ may be related to the $\mathrm{L}-\mathrm{L}$ doping technique described in the Experimental section. Thus, it is easy to understand that the doping processes for synthesizing HM- and SM-precursor powders was used to obtain containing-(Zr, Y) phase close together. In ZM system, upon hydrolysis of $\mathrm{ZrOCl}_{2} \cdot 8 \mathrm{H}_{2} \mathrm{O}, \mathrm{Cl}^{-}$ions in the outer sphere of the ionic complex are replaced by $\mathrm{OH}^{-}$ groups (Eq. 7), and $\left[\mathrm{Zr}_{4}(\mathrm{OH})_{8} \cdot 16 \mathrm{H}_{2} \mathrm{O}\right]^{8+}$ can react with hydroxyl ions to form fine $\mathrm{Zr}(\mathrm{OH})_{4}$ sols $[51,52]$. Meanwhile, the $\mathrm{Y}^{3+}$ ions react with hydroxyl ions to form fine $\mathrm{Y}(\mathrm{OH})_{3}$ sols, as confirmed by the acidity of $\mathrm{Y}\left(\mathrm{NO}_{3}\right)_{3} \cdot 6 \mathrm{H}_{2} \mathrm{O}$ solution $(\mathrm{pH}$ of 3 , similar to that of the AMT solution). Thus, the $\mathrm{ZrOCl}_{2} \cdot 8 \mathrm{H}_{2} \mathrm{O}$ solution should be firstly mixed with the $\mathrm{Y}\left(\mathrm{NO}_{3}\right)_{3} \cdot 6 \mathrm{H}_{2} \mathrm{O}$ solution to obtain composite colloids with $\mathrm{Zr}(\mathrm{OH})_{4}$ close to $\mathrm{Y}(\mathrm{OH})_{3}$.

$$
\left\{\left[\mathrm{Zr}_{4}(\mathrm{OH})_{8} \cdot 16 \mathrm{H}_{2} \mathrm{O}\right]^{8+}+8 \mathrm{Cl}^{-}\right\}+4 \mathrm{H}_{2} \mathrm{O}=\left\{\left[\mathrm{Zr}_{4}(\mathrm{OH})_{8} 16 \mathrm{H}_{2} \mathrm{O}\right]^{8+}+8 \mathrm{OH}^{-}\right\}+8 \mathrm{HCl} \uparrow(7)
$$

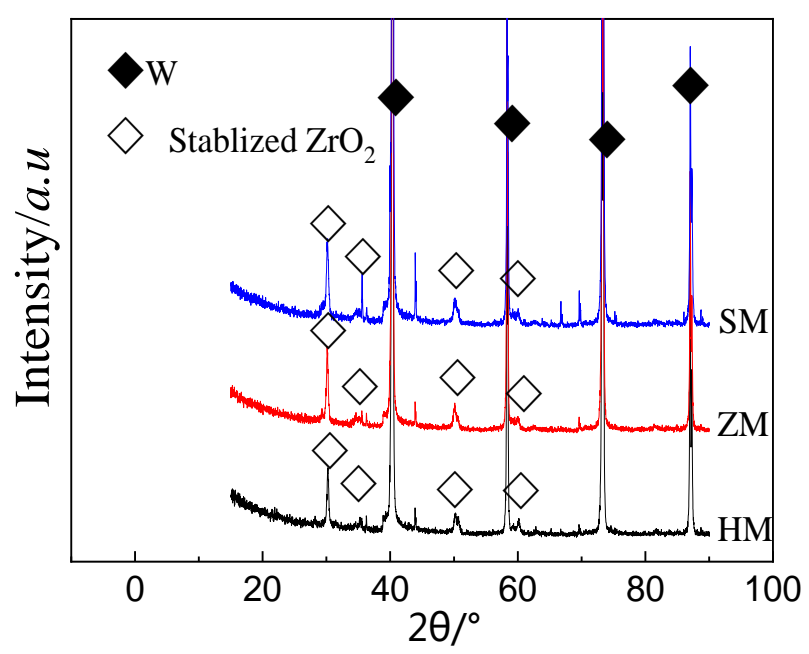

Fig. $7 \mathrm{XRD}$ patterns of three composite powders with $5.0 \% \mathrm{ZrO}_{2}(\mathrm{Y})$ reduced at $900{ }^{\circ} \mathrm{C}$ for $2 \mathrm{~h}$.

Mechanical properties are highly determined by the microstructure of materials. 
Based on the analysis of the microstructure, ZM-alloy exhibits excellent mechanical properties over the two other alloys. As listed in Table 5, ZM-alloy exhibits the highest density and microhardness of $16.48 \mathrm{~g} / \mathrm{cm}^{3}$ and $463 \mathrm{Hv}$, respectively. The value of compressive strength and critical failure strain are shown in Table 5 and Fig. 8. The values of the compressive strength of ZM-alloy at room and high temperatures reach to $1410 \mathrm{MPa}$ and $296 \mathrm{MPa}, 33.3 \%$ and $31.5 \%$ higher than those of HM-alloy, respectively. At room temperature, although the density of SM-alloy is lower than that of HM-alloy, the microhardness and high temperature compressive strength of the former are $32.2 \%$ and $17.8 \%$ higher than those of the latter. The compressive strength of SM-alloy at room temperature is similar to that of HM- alloy. Instead, the SM-alloy has higher compressive strength tested at at $1000{ }^{\circ} \mathrm{C}$. At room temperature, the critical failure strain of HM-alloy reaches to 0.18 . It shows the highest critical failure strain, and is appropriately $27.8 \%$ higher than that of ZM-alloy. However, at high temperature, ZM-alloy exhibits highest critical failure strain, this may be attributed to the highest density compared to other two alloy.
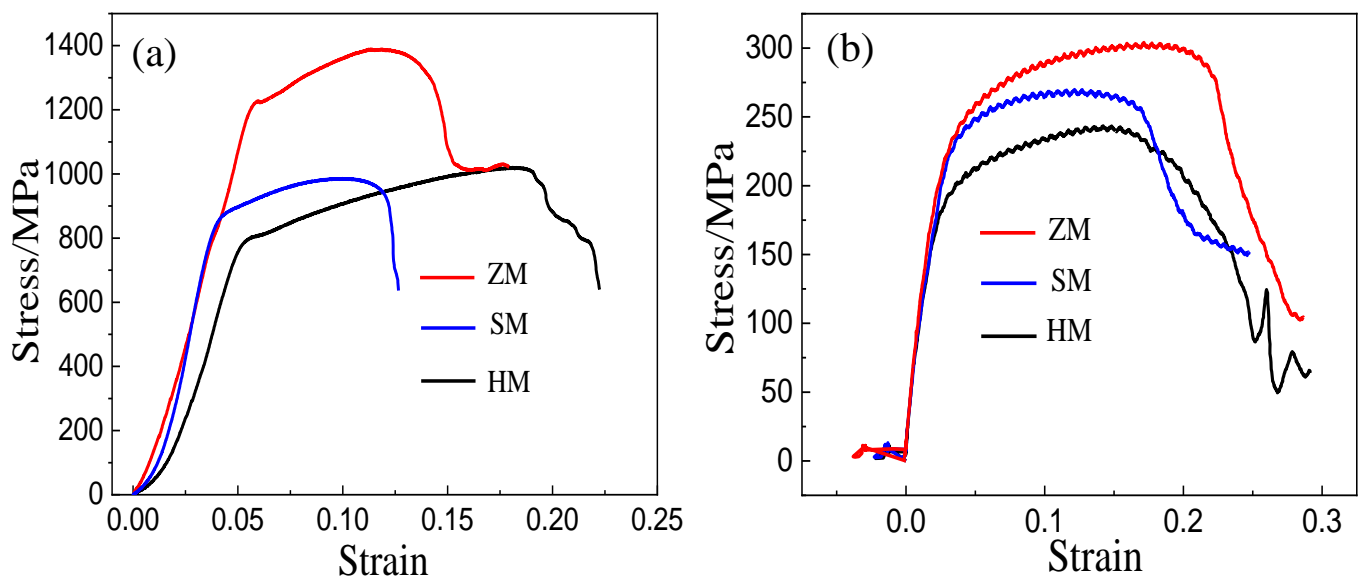

Fig. 8 Dynamic engineering stress-strain curves in the compressive testing (with imposed strain rate of $1.0 \mathrm{~s}^{-1}$ ): (a) at room temperature and (b) at $1000{ }^{\circ} \mathrm{C}$. 


\section{Discussion}

The physical characteristics of the precursor powder greatly affect the resultant reduced powders and further affect the microstructure and properties of alloy. It is necessary to study the influence of different liquid-liquid doping processes on the oxide distribution and precursor morphology.

In the experiment of preparing the SM- precursor powders, in order to obtaining containing-(Zr, Y) sols with good fluidity and uniform distribution, firstly, the original solution was prepared of $\mathrm{ZrOCl}_{2} \cdot 8 \mathrm{H}_{2} \mathrm{O}, \mathrm{YCl}_{3} \cdot 6 \mathrm{H}_{2} \mathrm{O}$ and $\left(\mathrm{NH}_{4}\right)_{6} \mathrm{H}_{2} \mathrm{~W}_{12} \mathrm{O}_{40} \cdot \mathrm{xH}_{2} \mathrm{O}$, and then the proper amount of ammonia was added into the original solution at room temperature. During raising the $\mathrm{pH}$ value of original solution to 6 , as these reaction (3) between the $\left(\mathrm{NH}_{4}\right)_{6} \mathrm{H}_{2} \mathrm{~W}_{12} \mathrm{O}_{40} \cdot \mathrm{xH}_{2} \mathrm{O}$ and $\mathrm{NH}_{3} \cdot \mathrm{H}_{2} \mathrm{O}$ occur slowly at room temperature, so the reactions between $\mathrm{Zr}^{4+}$ and $\mathrm{Y}^{3+}$ with $\mathrm{OH}^{-}$firstly occur, respectively, and then produce loose composite sol zirconium-yttrium hydroxide $\left[\mathrm{ZrY}(\mathrm{OH})_{\mathrm{x}}\right]$ in solution. Due to the addition of surface dispersant PEG, these fine composite soles were suspended in solution under high stirring. However, high concentrations of $\left(\mathrm{HW}_{12} \mathrm{O}_{39}{ }^{5-}\right)$ ions would penetrate into the gap between composite sols. Because of the increase of SM system' temperature, the reaction between $\left(\mathrm{HW}_{12} \mathrm{O}_{39}{ }^{5-}\right)$ ions and $\mathrm{OH}^{-}$occurs quickly and forms APT $4 \mathrm{H}_{2} \mathrm{O}$ sols. These APT sols would be surrounded by $\mathrm{ZrY}(\mathrm{OH})_{\mathrm{X}}$ sols as shown in Fig. 9a. Meanwhile, due to the high absorptivity resulted from larger surface area of APT $4 \mathrm{H}_{2} \mathrm{O}$ sols, the numerous neighbouring APT $4 \mathrm{H}_{2} \mathrm{O}$ sols aggregate together as shown in Fig. $9 \mathrm{~b}$, which results in the entrapment of $\mathrm{ZrY}(\mathrm{OH})_{\mathrm{x}}$ sols among APT $4 \mathrm{H}_{2} \mathrm{O}$ sols. 


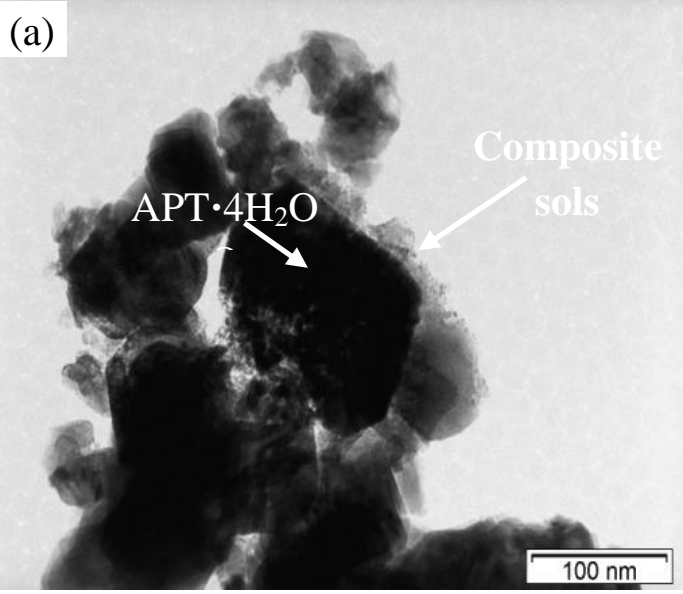

(b)

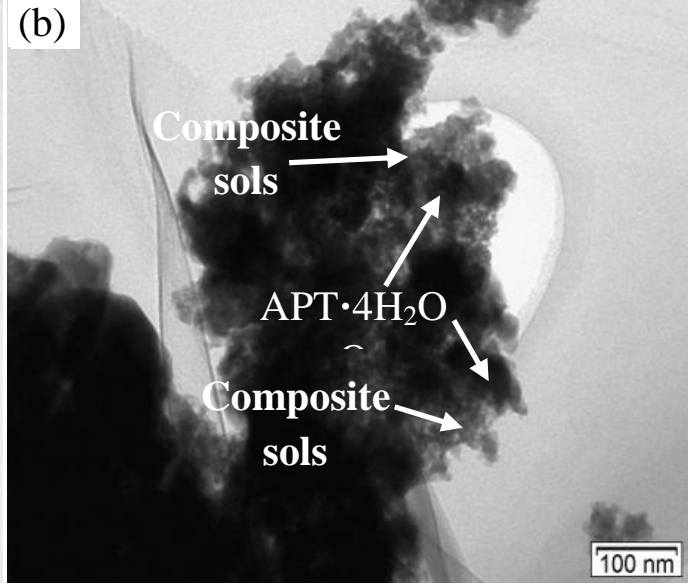

Fig. 9 TEM (a, b) images of precursor powders synthesized by sol-gel method.

For HM precursor, it is easy to observe that the microspheres consist of nanoplates as shown in Fig. 10a. TEM image shows that a lattice fringe was observed with a lattice spacing of $0.384 \mathrm{~nm}$ and identified as the (002) plane of hexagonal-phase $\left(\mathrm{NH}_{4}\right)_{0.33} \mathrm{WO}_{3} \cdot \mathrm{H}_{2} \mathrm{O}$, indicating the growth of nanoplates along the c-axis direction [53]. The $\mathrm{WO}_{3} \cdot \mathrm{nH}_{2} \mathrm{O}$ from the crystal cell is firstly formed by the hydrothermal reaction (Eq. 8) as shown in Fig. 10b. In this structure of $\mathrm{WO}_{3} \cdot \mathrm{nH}_{2} \mathrm{O}$, each oxygen atom is shared by two octahedrons, forming six-membered rings with numerous hexagonal and trigonal tunnels (Fig. 10c) [54-56]. These rings usually stack by sharing axial oxygen in the c axis [001] and form hexagonal prisms (Fig. 10d). In hydrothermal system, the high concentration of $\mathrm{NH}_{4}{ }^{+}$ions would occupy the hexagonal tunnels (Fig. 10c) $[57,58]$ and then accelerate the growth of hexagonal-prism $\mathrm{WO}_{3}$ along the [001] direction and then form the hierarchical $\left(\mathrm{NH}_{4}\right)_{0.33} \mathrm{WO}_{3} \cdot \mathrm{H}_{2} \mathrm{O}$ nanoplates. Finally, these nanoplates self-assemble together to form microspheres in order to reduce the high surface energy [59].

$$
\left(\mathrm{NH}_{4}\right)_{6} \mathrm{H}_{2} \mathrm{~W}_{12} \mathrm{O}_{40} \cdot \mathrm{xH}_{2} \mathrm{O}+6 \mathrm{HNO}_{3}=6 \mathrm{NH}_{4} \mathrm{NO}_{3}+12 \mathrm{WO}_{3} \cdot \mathrm{nH}_{2} \mathrm{O} \downarrow+(8-\mathrm{x}) \mathrm{H}_{2} \mathrm{O}
$$



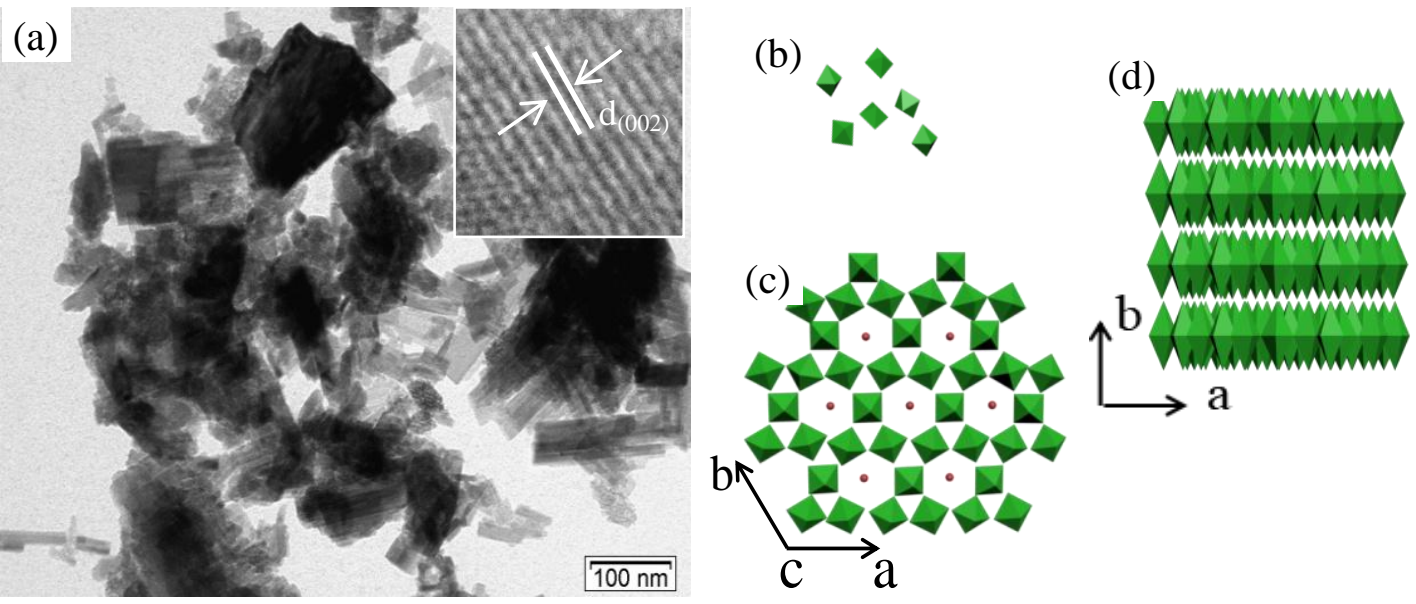

Fig. 10 (a) TEM images of the precursor powders synthesized through hydrothermal method; (b) Schematic diagram of the synthesis of nanoplate precursor.

Hard agglomerate formation is a consequence of the interaction of free water molecules with the free hydroxyls on the surface of the colloid particles through hydrogen bonds as shown in Fig. 11a. The physically absorbed water molecule will act as liquid bridges, which draw neighbouring particles together. As water is removed through drying, the hydrogen bonds between the hydroxyls on the surface of two neighbouring particles will draw them closer. In particular, calcination will cause the formation of strong chemical bonds and solid bridges between neighbouring particles, thereby increasing the degree of hard agglomerates.

As alcohol and water are mutually soluble, it is conductive to turn the wet gel into powders through removal of water in the wet colloid. However, the high evaporation rate of azeotropic substances (water and alcohol) decreases the dispersion effect of alcohol on wet colloids due to the lower azeotropic point (approximately $\left.78.5^{\circ} \mathrm{C}\right)$ of the water-alcohol system than the water bath temperature $\left(93^{\circ} \mathrm{C}\right)$, resulting in the formation of coarse gravel-likes particles (Fig. 3e).

In this study, the mixture of alcohol and butanol was used as azeotropic agent to 
increase the azeotropic point of the azeotropic substances (water, alcohol and butanol) and contribute to the formation of the flaky precursor powder (Fig. 3f). As the azeotropic substance vapours slowly and butanol dissolved easily in alcohol, once precipitates exist in the solution, butanol would cover precipitate with organic film, which would further form the organic molecular chains in the subsequent drying process. As a result, the hydroxyl groups on the particle surface will be replaced by organic molecular chains $\left(-\mathrm{OC}_{4} \mathrm{H}_{9}\right.$ group), hindering the particles to close together (Fig. 11b) [60]. In the following solvent removal process, there is little possibility of the formation of chemical bonds between neighbouring particles, obviating the possibility of the formation of the hard agglomerates. Meanwhile, the butoxy group has space blocking function that would prevent the approaching of particles [61]. Thus, flaky structure of AMT powder can be obtained.

(a)
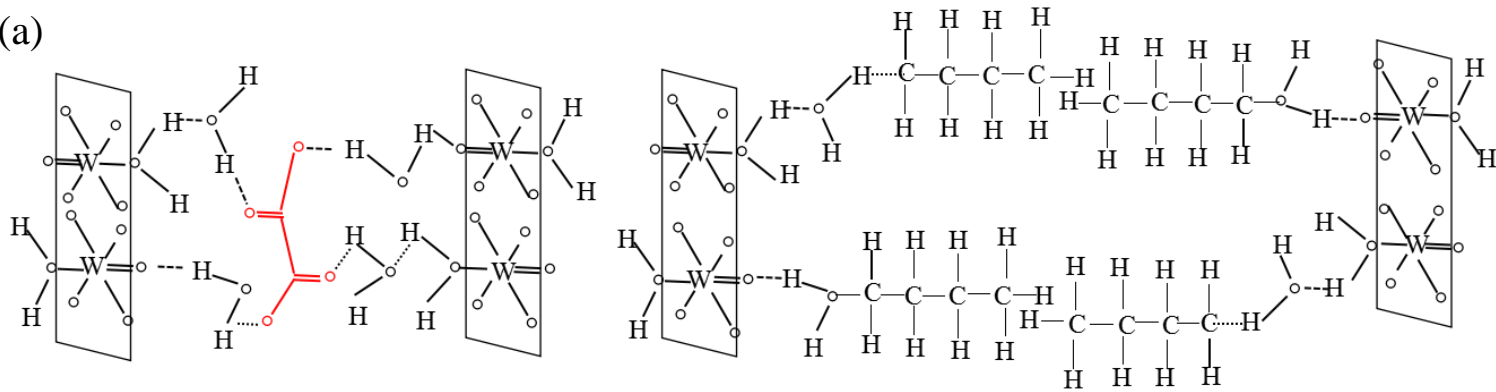

(b) 
Fig. 11 (a) The role of organic molecular chains with respect to the dehydration process of gravel-like doped AMT to flaky doped AMT; (b) Schematic flowchart of preventing from agglomerating during azeotropic distillation dehydration.

\section{Conclusions}

Three precursor powders such as doped h- $\left(\mathrm{NH}_{4}\right)_{0.33} \mathrm{WO}_{3} \cdot \mathrm{H}_{2} \mathrm{O}$, doped APT and doped AMT powders were synthesised through HM, SM and ZM, respectively. The different physical characteristics of $\mathrm{W}-\mathrm{ZrO}_{2}(\mathrm{Y})$ powders were obtained through calcination-continuous reduction.

$\mathrm{HM}$ and $\mathrm{ZM}$ can be used to synthesise extremely homogeneous microspherical and flaky precursor powders, respectively. The doped precursor powder prepared through SM is mainly composed of large square particles. The synthesis mechanisms of the three doped precursor powders were investigated. The doped powder through $\mathrm{ZM}$ was determined to have low reduction efficiency because of highly disperse and fine oxide particle among powders, leading to the smallest average particle size of the doped tungsten powders compared with those of the doped powders prepared through $\mathrm{HM}$ and SM. Moreover, the synthesis mechanisms of $\mathrm{Y}_{2} \mathrm{O}_{3}$-stabilised $\mathrm{ZrO}_{2}$ in the three doped powders were discussed.

The microstructures and mechanical properties of alloys obtained from three doped tungsten powders were analysed to confirm the excellent physical properties of doped powder obtained through ZM. The alloy prepared through ZM exhibits the smallest size of tungsten grains and $\mathrm{ZrO}_{2}(\mathrm{Y})$ particles, highest sintering densification and highest microhardness and dynamic compressive strength than the alloys prepared 
through HM and SM. Hence, ZM is an appropriate method for preparing high-quality $\mathrm{ZrO}_{2}(\mathrm{Y})$ doped tungsten powders.

\section{Conflicts of interest}

There are no conflicts to declare.

Founding: This work is supported by National Natural Science Foundation of China [No. 51672070; No. 51874185], Henan province science and technology innovation talent plan, China [No. 2017JQ0012] and Graduate Research and Innovation Projects in Jiangsu Province [ No. KYCX19_0182]. This work also has been supported by the EIPHI Graduate School (contract ANR-17-EURE-0002).

\section{Acknowledgements}

We would like to thank all the researchers who participated in our works discussed in the paper and whose names appear in references.

\section{Reference}

[1] L. Z. Wang, J. J. Wu, D. J. Zhang, Properties evolution of additive manufacture used tungsten powders prepared by radio frequency induction plasma, Int. J. Refract. Met. Hard Mater. 67 (2017) 90-97. https://doi.org/10.1016/j.ijrmhm.2017.05.007.

[2] C. C. Wang, C. C. Jia, P. Gao, Spherical modification of tungsten powder by particle composite system, Rare Met. (2015) 1-5. https://doi.org/10.1007/s12598-015-0546-X.

[3] F. N. Xiao, L. J. Xu, Y. C. Zhou, K. M. Pan, J. W. Li, W. Liu, S. Z. Wei, Preparation, microstructure, and properties of tungsten alloys reinforced by $\mathrm{ZrO}_{2}$ particles, Int. J. Refract. Met. Hard Mater. 64 (2017) 40-46. 
[4] J. W. Davis, V. R. Barabash, A. Makhankov, L. Plochl, K. T. Slattery, Assessment of tungsten for use in the ITER plasma facing components, J. Nucl. Mater. 258 (1998) 308-312. https://doi.org/10.1016/S0022-3115(98)00285-2.

[5] M. Mabuchi, K. Okamoto, N. Saito, M. Nakanishi, Y. Yamada, T. Asahina, T. Igarashi, Tensile properties at elevated temperature of $\mathrm{W}-1 \% \mathrm{La}_{2} \mathrm{O}_{3}$, Mater. Sci. Eng. A. 214 (1996) 174-176. https://doi.org/10.1016/0921-5093(96)10377-4.

[6] M. Mabuchi, K. Okamoto, N. Saito, T. Asahina, T. Igarashi, Deformation behavior and strengthening mechanisms at intermediate temperatures in $\mathrm{W}-\mathrm{La}_{2} \mathrm{O}_{3}$, $\begin{array}{lllll}\text { Mater. } & \text { Sci. } & \text { Eng. } & \text { A. } & 237\end{array}$ https://doi.org/10.1016/S0921-5093(97)00420-6.

[7] H. J. Ryu, S. H. Hong, Fabrication and properties of mechanically alloyed oxide-dispersed tungsten heavy alloys, Mater. Sci. Eng. A. 363 (2003) 179-184. https://doi.org/10.1016/S0921-5093(03)00641-5.

[8] M. N. Avettand,Fenoel, R. Taillard, J. Dhers, J. Foct, Effect of ball milling parameters on the microstructure of $\mathrm{W}-\mathrm{Y}$ powders and sintered samples, Int. J. Refract. Met. Hard Mater. $21 \quad$ (2003) 205-213. https://doi.org/10.1016/S0263-4368(03)00034-9.

[9] Y. Shen, Z. Xu, K. Cui, J. Yu, Microstructure of a commercial W-1\% $\mathrm{La}_{2} \mathrm{O}_{3}$ alloy, J. Nucl. Mater. 455 (2014) 234-241. https://doi.org/10.1016/j.jnucmat.2014.06.004. [10] S. Qu, S. Gao, Y. Yuan, C. Li, Y. Lian, X. Liu, W. Liu, Effects of high magnetic field on the melting behavior of $\mathrm{W}-1 \mathrm{wt} \% \mathrm{La}_{2} \mathrm{O}_{3}$ under high heat flux, J. Nucl. Mater. 463 (2015) 189-192. https://doi.org/10.1016/j.jnucmat.2014.10.085. 
[11] X. Yang, Z. Xie, S. Miao, R. Liu, W. Jiang, T. Zhang, X. Wang, Q. Fang, C. Liu, G. Luo, Tungsten-zirconium carbide-rhenium alloys with extraordinary thermal stability, $\quad$ Fusion $\quad$ Eng. $\quad$ Des. $106 \quad$ (2016) 56-62. https://doi.org/10.1016/j.fusengdes.2016.03.063.

[12] R. Li, M. Qin, C. Liu, Z. Chen, X. Wang, X. Qu, Particle size distribution control and related properties improvements of tungsten powders by fluidized bed jet milling, Adv. Powder $\quad$ Technol. $28 \quad$ (2017) 1603-1610. https://doi.org/10.1016/j.apt.2017.04.002.

[13] W. He, D. Q. Tan, Y. L. Li, X. Yang, L. Lu, D. P. Lu, Effect of rare earth element cerium on preparation of tungsten powders, J. Rare. Earth. 33 (2015) 561-566. https://doi.org/10.1016/S1002-0721(14)60456-7.

[14] L. Z. Wang, J. J. Wu, D. J. Zhang, Properties evolution of additive manufacture used tungsten powders prepared by radio frequency induction plasma, Int. J. Refract. Met. Hard Mater. 67 (2017) 90-97. https://doi.org/10.1016/j.ijrmhm.2017.05.007.

[15] R. Kiran, Effect of $\mathrm{WO}_{3}$ powder particle shape, size and bulk density, on the grain size and grain size distribution of tungsten metal powder, Met. Powder. Rep. 71 (2016) 285-287. https://doi.org/10.1016/j.mprp.2016.05.007.

[16] B. Mamen, J. Song, T. Barriere, J. C. Gelin, Experimental and numerical analysis of the particle size effect on the densification behaviour of metal injection moulded tungsten parts during sintering, Powder Technol. $270 \quad$ (2015) 230-243. https://doi.org/10.1016/j.powtec.2014.10.019.

[17] X. Fu, D. Huck, L. Makein, B. Armstrong, U. Willen, T. Freeman, Effect of 
particle shape and size on flow properties of lactose powders, Particuology. 10 (2012) 203-208. https://doi.org/10.1016/j.partic.2011.11.003.

[18] J. F. Gamble, W. Chiu, M. Tobyn, Investigation into the impact of sub populations of agglomerates on the particle size distribution and flow properties of conventional microcrystalline cellulose grades, Pharm. Dev. Technol. 16 (2011) 542-548. https://doi.org/10.3109/10837450.2010.495395.

[19] G. J. Zhang, Y. J. Sun, R. M. Niu, J. Sun, J. F. Wei, B. H. Zhao, L. X. Yang, Microstructure and strengthening mechanism of oxide lanthanum dispersion strengthened molybdenum alloy, Adv. Eng. Mater. 6 (2004) 943-948. https://doi.org/10.1002/adem.200400072.

[20] G. Gai, Y. Yang, L. Jin, X. Zou, Y. Wu, Particle shape modification and related property improvements, Powder Technol. $183 \quad$ (2008) 115-121. https://doi.org/10.1016/j.powtec.2007.11.026.

[21] U. R. Kiran, M. P. Kumar, M. Sankaranarayana, K. Singh, T. K. Nandy, High energy milling on tungsten powders, Int. J. Refract. Met. Hard Mater. 48 (2015) 74-81. https://doi.org/10.1016/j.ijrmhm.2014.06.025.

[22] Z. Dong, N. Liu, Z. Ma, Synthesis of nanosized composite powders via a wet chemical process for sintering high performance $\mathrm{W}-\mathrm{Y}_{2} \mathrm{O}_{3}$ alloy, Int. J. Refract. Met. Hard Mater. 69 (2017) 266-272. https://doi.org/10.1016/j.ijrmhm.2017.09.001.

[23] T. Ryu, K. S. Hwang, Y. J Choi, The sintering behaviour of nanosized tungsten powder prepared by a plasma process, Int. J. Refract. Met. Hard Mater. 27 (2009) 701-704. https://doi.org/10.1016/j.ijrmhm.2008.11.004. 
[24] M. A. Yar, S. Wahlberg, H. Bergqvist, Chemically produced nanostructured ODS-lanthanum oxide-tungsten composites sintered by spark plasma, J. Nucl. Mater. 408 (2011) 129-135. https://doi.org/10.1016/j.jnucmat.2010.10.060.

[25] M. A. Yar, S. Wahlberg, H. Bergqvist, Spark plasma sintering of tungsten-yttrium oxide composites from chemically synthesised nanopowders and microstructural characterization, J. Nucl. Mater. 412 (2011) 227-232. https://doi.org/10.1016/j.jnucmat.2011.03.007.

[26] G. Liu, G. J. Zhang, F. Jiang, X. D. Ding, Y. J. Sun, J. Sun, E. Ma, Nanostructured high-strength molybdenum alloys with unprecedented tensile ductility, Nat. Mater. 12 (2013) 344-350. https://doi.org/10.1038/nmat3544.

[27] Y. Hua, J. Wang, J. Ma, Effect of yttrium doping on the formation and stability of $\beta$-tungsten powder, Int. J. Refract. Met. Hard Mater. 72 (2018) 71-77. https://doi.org/10.1016/j.ijrmhm.2017.12.006.

[28] C. Lai, J. Wang, F. Zhou, Reduction, sintering and mechanical properties of rhenium -tungsten compounds, J. Alloy. Compd. 735(2018) 2685-2693. https://doi.org/10.1016/j.jallcom.2017.11.064.

[29] Y. T. Cui, J. S. Wang, W. Lui, X. Wang, Effect of scandia on tungsten oxide powder reduction process, J. Rare. Earth. 28 (2010) 202-205. https://doi.org/10.1016/s1002-0721(10)60274-8.

[30] S. H. Hong, B. K. Kim, Fabrication of W-20 wt\% Cu composite nanopowder and sintered alloy with high thermal conductivity, Mater. Lett. 57 (2003) 2761-2767. https://doi.org/10.1016/S0167-577X(03)00071-5. 
[31] L. Xu, Q. Yan, M. Xia, L. Zhu, Preparation of $\mathrm{La}_{2} \mathrm{O}_{3}$ doped ultra-fine W powders by hydrothermal-hydrogen reduction process, Int. J. Refract. Met. Hard Mater. 36(36), 238-242.

[32] M. L. Zhao, L. M. Luo, J. S. Lin, X. Zan, X. Y. Zhu, G. N. Luo, Y. C. Wu, Thermal shock behavior of $\mathrm{W}-0.5 \mathrm{wt} \% \quad \mathrm{Y}_{2} \mathrm{O}_{3}$ alloy prepared via a novel chemical method, J. Nucl. Mater. $479 \quad$ (2016) 616-622. https://doi.org/10.1016/j.jnucmat.2016.07.049.

[33] R. Liu, Z. Xie, Q. Fang, T. Zhang, X. Wang, T. Hao, C. Liu, Y. Dai, Nanostructured yttria dispersion-strengthened tungsten synthesised by sol-gel method, J. Alloy. Compd. 657 (2016) 73-80. https://doi.org/10.1016/j.jallcom.2015.10.059.

[34] H. Zhu, D. Tan, Y. Li, X. Yang, W. He, Refining mechanisms of arsenic in the hydrogen reduction process of tungsten oxide, Adv. Powder Technol. 26 (2015) 1013-1020. https://doi.org/10.1016/j.apt.2015.04.007.

[35] M. B. Macinnis, T. K. Kim, The impact of solvent extraction and ion exchange on the hydrometallurgy of tungsten and molybdenum, J. Chem. Technol. Biot. 29 (1979) 225-231. https://doi.org/10.1002/jctb.503290404.

[36] F. Xiao, L. Xu, Y. Zhou, K. Pan, J. Li, W. Liu, S. Wei, A hybrid microstructure design strategy achieving $\mathrm{W}-\mathrm{ZrO}_{2}(\mathrm{Y})$ alloy with high compressive strength and critical failure strain, J. Alloy. Compd. $708 \quad$ (2017) 202-212. https://doi.org/10.1016/j.jallcom.2017.02.277.

[37] B. Liu, A. Shi, Q. Su, Recovery of tungsten carbides to prepare the ultrafine WC-Co composite powder by two-step reduction process, Powder Technol. 306 (2017) 
113-119. https://doi.org/10.1016/j.powtec.2016.10.071.

[38] W.D. Schubert, E. Lassner, Production and characterization of hydrogen-reduced submicron tungsten powders. Part II: Controlled decomposition of APT and hydrogen reduction of the oxides, Int. J. Refract. Met. Hard Mater. 10 (1991) 171-183. https://doi.org/10.1016/0263-4368(91)90031-I.

[39] F. N. Xiao, Q. Miao, S. Z. Wei, Z. Li, T. L. Sun, L. J. Xu, Microstructure and mechanical properties of $\mathrm{W}-\mathrm{ZrO}_{2}$ alloys by different preparation techniques, $\mathrm{J}$ Alloys Compd, 774 (2019): 210-221.

[40] F. N. Xiao, Q. Miao, S. Z. Wei, Hydrothermal synthesis of nanoplates assembled hierarchical $\mathrm{h}-\mathrm{WO}_{3}$ microspheres and phase evolution in preparing cubic $\mathrm{Zr}(\mathrm{Y})$ $\mathrm{O}_{2}$-doped tungsten powders, Adv. Powder Technol. 29 (2018) 2633-2643. https://doi.org/10.1016/j.apt.2018.07.011.

[41] F. N. Xiao, Q. Miao, S. Z. Wei, T. Barriere, G. Cheng, S. W. Zuo, L. J. Xu, Uniform nanosized oxide particles dispersion strengthened tungsten alloy fabricated involving hydrothermal method and hot isostatic pressing, J Alloys Compd, 824 (2020): 153894. https://doi.org/10.1016/j.jallcom.2020.153894.

[42] Z. Li, L. J. Xu, S. Z. Wei, C. Chen, F. N. Xiao, Fabrication and mechanical properties of tungsten alloys reinforced with $\mathrm{c}-\mathrm{ZrO}_{2}$ particles, J. Alloy. Comp. 769 (2018) 694-705.

[43] F. Pan, Q. Zhu, S. Li, Decomposition-carbonization of ammonium paratungstate in a fluidized bed, Int. J. Refract. Met. Hard Mater. 72 (2018) 315-322. https://doi.org/10.1016/j.ijrmhm.2017.12.032. 
[44] M. J. G. Fait, E. Moukhina, M. Feist, Thermal decomposition of ammonium paratungstate tetrahydrate: new insights by a combined thermal and kinetic analysis, Thermochim. Acta. 637 (2016) 38-50. https://doi.org/10.1016/j.tca.2016.05.009.

[45] M. S. Marashi, J.V. Khaki, S. M. Zebarjad, Direct solid state synthesis of $\mathrm{W}-\mathrm{Al}_{2} \mathrm{O}_{3}$ nanostructured composite using ammonium paratungstate (APT) and $\mathrm{Al}$ powder mixture, Int. J. Refract. Met. Hard Mater. 43 (2014) 13-18.

[46] L. J. Xu, F. N. Xiao, S. Z. Wei, Y. C. Zhou, K. M. Pan, X. Q. Li, J. W Li, W. L, Development of tungsten heavy alloy reinforced by cubic zirconia through liquid-liquid doping and mechanical alloying methods, Int. J. Refract. Met. Hard Mater. 78 (2019) 1-8. https://doi.org/10.1016/j.ijrmhm.2018.08.009.

[47] R. H. Piva, D. H. Piva, J. J. Pierri, Azeotropic distillation, ethanol washing, and freeze drying on coprecipitated gels for production of high surface area 3Y-TZP and 8YSZ powders: A comparative study, Ceram. Int. 41 (2015) 14148-14156. https://doi.org/10.1016/j.ceramint.2015.07.037.

[48] S. W. Zha, Q. X. Fu, Y. Lang, C. G. Xia, G. Y. Meng, Novel azeotropic distillation process for synthesizing nanoscale powders of yttria doped ceria $\begin{array}{lllll}\text { electrolyte, } & \text { Mater } & \text { Lett. } & 47 & \text { (2001) 351-355. }\end{array}$ https://doi.org/10.1016/S0167-577X(00)00265-2.

[49] T. Sarmah, N. Aomoa, G. Bhattacharjee, Plasma expansion synthesis of tungsten nanopowder, J. Alloy. Compd. $725 \quad$ (2017) 606-615. https://doi.org/10.1016/j.jallcom.2017.07.207. [50] Y. Han, J. Fan, T. Liu, H. C. Cheng, J. M. Tian, The effects of ball-milling 
treatment on the densification behavior of ultra-fine tungsten powder, Int. J. Refract. Met. Hard Mater. 29 (2011) 743-750. https://doi.org/10.1016/j.ijrmhm.2011.06.010. [51] G. Y. Guo, Y. L. Chen, W. J. Ying, Thermal, spectroscopic and X-ray diffractional analyses of zirconium hydroxides precipitated at low $\mathrm{pH}$ values, Mater. Chem. Phys. 84 (2004) 308-314. https://doi.org/10.1016/j.matchemphys.2003.10.006. [52] V. B. Glushkova, A. N. Lapshin, Specific features in the behavior of amorphous zirconium hydroxide: I. Sol-gel processes in the synthesis of zirconia, Glass. Phys. Chem. 29 (2003) 415-421. https://doi.org/10.1023/A:1025137313344.

[53] S. Cao, H. Chen, Nanorods assembled hierarchical urchin-like WO3 nanostructures: Hydrothermal synthesis, characterization, and their gas sensing $\begin{array}{llllll}\text { properties, } & \text { J. } & \text { Alloy. } & \text { Compd. } & 702 & \text { (2017) }\end{array}$ https://doi.org/10.1016/j.jallcom.2017.01.232.

[54] L. Z. L, J. Z. Zhao, Y.Wang, Y. L. Li, D. C. Ma, Y. Zhao, S. N. Hou, X. L. Hao, Oxalic acid mediated synthesis of WO3-H2O nanoplates and self-assembled nanoflowers under mild conditions, J. Solid. State. Chem. 184 (2011) 1661-1665. https://doi.org/10.1016/j.jssc.2011.05.008.

[55] M. Q. Xu, W. Zeng, F. Yang, L. Chen, Controllability of assemblage from $\mathrm{WO}_{3}-\mathrm{H}_{2} \mathrm{O}$ nanoplates to nanoflowers with the assistance of oxalic acid, J. Mater. Sci-Mater. El. 26 (2015) 6676-6682. https://doi.org/10.1007/s10854-015-3269-8.

[56] B. Miao, W. Zen, S. H. Hussain, Q. P. Mei, S. B. Xu, H. Zhang, Y. Q. Li, T. M. Li, Large scale hydrothermal synthesis of monodisperse hexagonal WO3 Nanowire and the growth mechanism, Mater Lett. 147 (2015)12-15. 
https://doi.org/10.1016/j.matlet.2015.02.020.

[57] L. Zhang, X. C. Tang, Z. G. Lu, Z. M. Wang, L. X. Li, Y. H. Xiao. Facile synthesis and photocatalytic activity of hierarchical WO3 core-shell microspheres, Appl. Surf. Sci. 258 (2011) 1719-1724. https://doi.org/10.1016/j.apsusc.2011.10.022. [58] Jang-Hoon Ha, P. Muralidharan, Do Kyung Kim, Hydrothermal synthesis and characterization of self-assembled $\mathrm{h}-\mathrm{WO}_{3}$ nanowires/nanorods using EDTA salts, $\mathrm{J}$. Alloy. Compd. 475 (2009) 446-451.

[59] F. N. Xiao, T. Barriere, G. Cheng, Q. Miao, S. Z. Wei, S. W. Zuo, Z. M. Huang, L. J. Xu, Research on preparation process for the in situ nanosized $\mathrm{Zr}(\mathrm{Y}) \mathrm{O}_{2}$ particles dispersion-strengthened tungsten alloy through synthesizing doped hexagonal $\left(\mathrm{NH}_{4}\right)_{0.33} \cdot \mathrm{WO}_{3}$

[60] H. C. Yao, X. W. Wang, H. Dong, R. R. Pei, J. S. Wang, Z. J. Li, Synthesis and characteristics of nanocrystalline YSZ powder by polyethylene glycol assisted coprecipitation combined with azeotropic-distillation process and its electrical conductivity, $\quad$ Ceram. $\quad$ Int. $37 \quad$ (2011) 3153-3160. https://doi.org/10.1016/j.ceramint.2011.05.055.

[61] S. W. Zha, Q. X. Fu, Y. Lang, C. G. Xia, G. Y. Meng, Novel azeotropic distillation process for synthesizing nanoscale powders of yttria doped ceria $\begin{array}{llllll}\text { electrolyte, } & \text { Mater } & \text { Lett. } & 47 & \text { (2001) 351-355. }\end{array}$ https://doi.org/10.1016/S0167-577X(00)00265-2. 